Original Research Paper

\title{
Building Resilience in Natural Capital to Reduce Disaster Risks and Adapt to Climate Change: A Case of Wetlands in the Eastern Free State; South Africa
}

\author{
${ }^{1}$ Johanes A. Belle, ${ }^{2}$ Nacelle Collins and ${ }^{3}$ Andries Jordaan \\ ${ }^{1,3}$ Disaster Management Training and Education Centre for Africa, University of the Free State, \\ Bloemfontein, South Africa \\ ${ }^{2}$ Department of Environmental Affairs, University of the Free State, Bloemfontein, South Africa
}

Article history

Received: 13-06-2017

Revised: $14-07-2017$

Accepted: 02-10-2017

Corresponding Author:

Johanes A. Belle

University of the Free State;

Disaster Management Training

and Education Centre for Africa;

Bloemfontein, South Africa

Tel: +27 782224755

Fax: +27514019336

Email: Belleja@ufs.ac.za

\begin{abstract}
Wetlands are a form of natural capital which provide services that improve the welbeing of the local community. Unfortunately many wetlands have been degraded before their values and functions were realised. Using a system thing appraoach and a mixed research method, this article collected primary data from 176 respondents using questionnaires. Besides, 21 wetlands were observed using field observation data sheet while interviews were conducted with 31 environmental, disaster and climate change experts. Lastly secondary data were obtained from the South Africa Weather Service on two climate parameters. All these data were used to investigate the vulnerability and functions of wetlands as a natural capital and how to build wetland resilience in the eastern Free State of South Africa. The main findings were that wetlands especially those in communal land were still very vulnerable partly due to ignorance of wetland values and functions. The dominant function of the wetlands in the study area was agriculture (both crop production and grazing). These wetlands also perform other functions that support the welbeing and safety of the local community. Despites these valuable functions, wetland degradation is still going on and the management is still predominantly reactive. The main recommendation therefore was a proposed integrated management framework that build wetland resilience to the changing environment characterised by increasing extreme weather events and disaster risks exacerbated by negative impacts of climate change.
\end{abstract}

Keywords: Community Capitals, Wetlands, Vulnerability, Resilience

\section{Introduction}

Building community and system resilience is a new paradigm shift and focus area in international discussions on disaster risk reduction, climate change adaptation and sustainable development (Renaud et al., 2016). The concept and application of resilience found much resonance in many international conferences recently. This was the case of the World Conference on Disaster Risk Reduction in March 2015 in Sendai; Japan. This conferences culminated in the formulation of the Sendai Framework for Disaster Risk Reduction (SFDR) with much emphasis on ecosystembased approach to build community resilience (UNISDR,
2015). In the same 2015, the COP 21 on climate change was held in Paris and this gave birth to the Paris Agreement which also emphasized on climate resilient communities using ecosystems approach (UNFCCC, 2015). The Sustainable Development Goals (SDGs) which replaced the Millennium Development Goals (MDGs) in 2015 also highlighted the need for resilient-prone development projects and programmes using natural ecosystems (UNDP, 2015). All these global platforms emphasized the need for ecosystem-based approach in building systems and community resilience. Wetlands were often cited as an important ecosystem for disaster risk reduction, climate change adaptation and for sustainable development. The 
rationale of this paper is therefore well grounded within recent international discussions.

Wetlands are transitional areas between aquatic and terrestrial surfaces with much water on or near the surface for a long time of the year that creates water-logging condition, hydric soils and are vegetated by hydrophytes or water-tolerant plants (RSA, 1998). The Ramsar Convention on Wetlands definition of wetlands include marsh, fen, peatland or water which is natural or artificial, permanent or temporary, static or flowing, fresh or brackish, salt and marine areas less or equal to six metres at low tides (RCS, 2010). These two definitions are almost the same but differ in the fact that while dams and rivers may be included in the Ramsar Convention on Wetlands definition, this is not the case with the South Africa definition though dams and rivers are considered as part of the inland fresh water systems alongside wetlands (Ollis et al., 2013).

South Africa is a water stressed and water scarce country. It is also a country with wetlands. The Free State province has about 54000 wetlands of different types that include valley bottom, flood plains, seeps, pans or depressions and riverine wetlands (Collins, 2006; 2011; Ollis et al., 2013; SANBI, 2010 in Nel et al., 2011). The eastern Free State (eFS) in this study was arbitrarily demarcated but was large enough to permit a good sample of valley bottom wetlands. An estimated
2624 of such wetlands exist and these are the dominant wetland type in the area.

The study area also closely followed the 500-700 mm rainfall datum, east of which permits rain-fed agriculture (Fig. 1).

Agriculture (both crop production and animal rearing) is the dominant activity in the whole of the Free State province. The province is commonly referred to as the granary or food basket of south and southern Africa.

Valley bottom wetlands are one of the hydrogeormorphic wetland types (Fig. 2) of the inland wetland systems in South Africa (Table 1) (Collins, 2006; Kotze et al., 2007, Ollis et al., 2013).

About $50 \%$ of South Africa wetlands have been seriously degraded or lost (Grundling, 2012; Kotze et al., 2009). This destruction sometimes go up to $90 \%$ in some tertiary catchments (Grundling 2012). Most of the degradation took place before the real values of wetlands were understood by the local communities (MEA, 2005; TEEB, 2010). There is still abundant evidence of continued wetland degradation in the water scarce South Africa including the eastern Free State. Wetlands degradation is also taking place amidst conditions of increasing extreme weather events like drought and floods as well as other negative impacts associated with climate change such as rising temperature (IPCC, 2007; 2014).

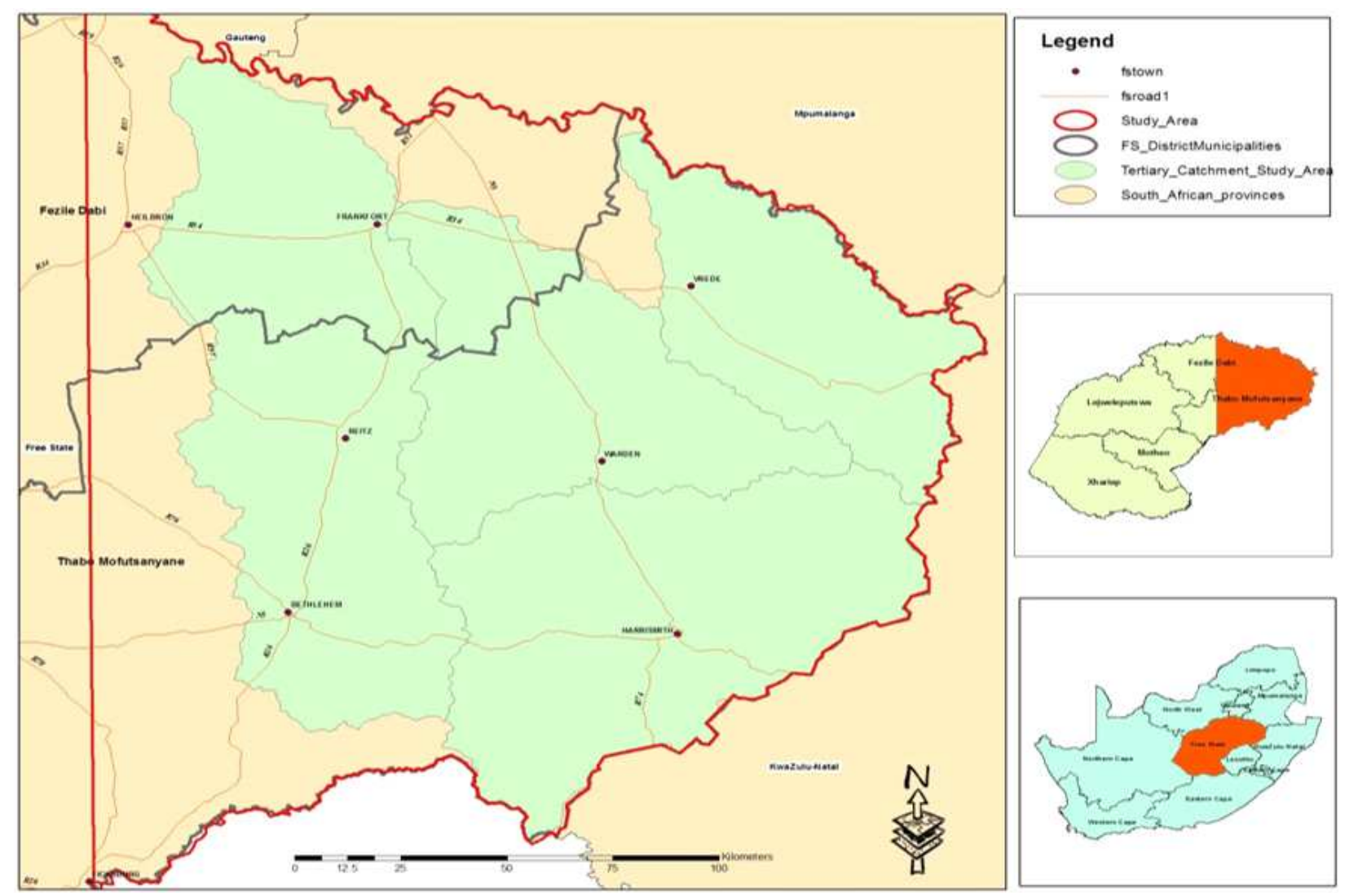

Fig. 1. The location of the study area in the Free State (FS) Province, Source: Author's own (2016) 


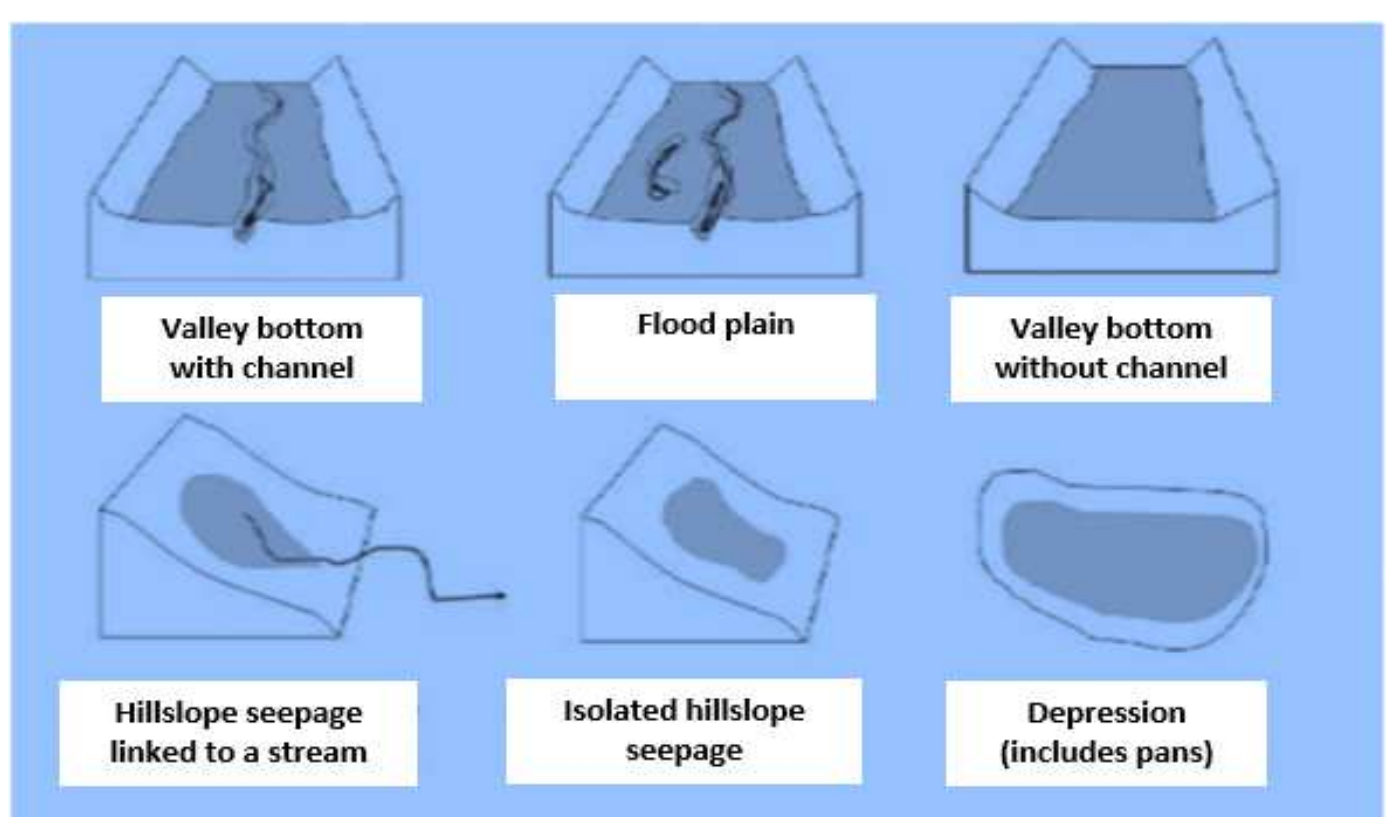

Fig. 2. Thehydrogeomorphic classification of wetlands, Source: Kotze et al. (2007)

Table 1. South Africa wetlands inventory categories

\begin{tabular}{|c|c|c|}
\hline Category & Description & Examples \\
\hline Marine system & $\begin{array}{l}\text { Are part of the open ocean overlying the continental } \\
\text { shelf and/or its associated coastline, but not exceeding } \\
\text { a depth of } 10 \mathrm{~m} \text { at low tide, i.e., not extending beyond } \\
\text { the shallow photic zone }\end{array}$ & $\begin{array}{l}\text { Coral reefs, rocky shores, } \\
\text { wave cut platforms and } \\
\text { sandy or pebble beaches }\end{array}$ \\
\hline Estuarine systems & $\begin{array}{l}\text { Partially enclosed ecosystems that are permanently or } \\
\text { periodically connected to the ocean, which are influenced } \\
\text { by tidal fluctuations and within which ocean water is at } \\
\text { least occasionally diluted by fresh water derived from } \\
\text { surface or subsurface land drainage }\end{array}$ & $\begin{array}{l}\text { Lagoons, estuarine lakes } \\
\text { and river mouths }\end{array}$ \\
\hline Inland systems & $\begin{array}{l}\text { Are permanently or periodically inundated or saturated } \\
\text { systems that has no existing connection to the ocean and } \\
\text { complete absence of marine exchange and/or tidal } \\
\text { influence. Most wetland fall in this category }\end{array}$ & $\begin{array}{l}\text { Rivers, seeps, pans, } \\
\text { floodplains, } \\
\text { marshes, peatlands }\end{array}$ \\
\hline
\end{tabular}

Source: Adapted from Ollis et al. (2013)

Wetlands can play a critical role in reducing disaster risks, adapting to climate change and promoting sustainable development through its valuable provisioning, regulatory, supporting and cultural services (MEA, 2005; Renaud et al., 2013; 2016). For wetlands to perform these multiple functions, it is important that we humans "help-wetlands-help-us" by promoting wetland resilience through wise and sustainable management (Gitay et al., 2011; Kidd, 2011; Kotze et al., 2009; UNEP, 2009). This paper therefore examines wetlands as an important natural capital to the local communities. Natural capital are all the natural environmental assets that a community possess (Mattos, 2015; Peters, 2016). To promote the quality of wetlands as a natural capital, this paper proposes a framework for building wetland resilience to external stressors in the study area.

\section{Materials and Methods}

\section{Theoretical and Conceptual Frameworks}

\section{Philosophical Approach}

The study was about an empirical or a real-world issue (Mouton, 2001) and a synthesis of the postpositivist and interpretivist approaches influenced the philosophical orientation of the study (Babbie et al., 2008; Bertram and Christiansen, 2014; De Vos et al., 2005; Kitchin and Tate, 2000; Maree, 2007; Okeke and Van Wyk, 2015). The post-positivist approach is suitable for real-world problems such as the one this research investigated in order to come up with remedial solutions. Besides, post-positivists use multiple methods and a variety of measures to capture as much reality as possible (Van Wyk, 2016). Post-positivism permits a 
small sample size and the freedom for researchers to create measuring instruments (Okeke and Van Wyk, 2015; Van Wyk, 2016). The post-positivism progressively generates cumulative knowledge that can produce objective, generalisable information, using facts (Fabinyi et al., 2014). Most of these ingredients of post-positivism are evident in the research method that was followed.

While using mainly the research lens of the postpositivist approach, this study also incorporated the more interpretivist traditions in social science (Creswell, 2003; Fabinyi et al., 2014) to create a holistic and balanced outcome, as well as to interpret the collected data using questionnaires (Bertram and Christiansen, 2014). The fact that humans and their experiences were involved in wetlands management brings in the social dimension of this research and this aspect relates very well with the interpretivist paradigm. This paradigm normally seeks to describe and understand how people make use of their world, in this case their wetlands (Creswell, 2003; Bertram and Christiansen, 2014). The close interaction between the researcher and the respondents during questionnaire administration and field observation tallied with the interpretivist approach. Meanwhile, detailed objective description of the collected data that reflected the experiences of the respondents on wetlands management informed the final conclusions in line with the interpretivist paradigm (Bertram and Christiansen, 2014).

This study involved both natural (wetlands) and social sciences (people and the management of wetlands); it was a survey using mixed method and multiple tools for data collection; the study generated both quantitative and qualitative data and the study used a pre-test like the pilot test. Given the fact that surveys are often used in the post-positivist, but also increasingly used in the interpretivist approach in recent years, justified the combination of the post-positivism and the interpretivism paradigms in this study.

\section{Conceptual Outline of the Study}

This was a interdisciplinary study involving three main disciplines that included environmental management with a focus on Wetlands Management (WM), disaster management with a focus on Disaster Risk Reduction (DRR) and climate change science with a focus on Climate Change Adaptation (CCA). All these are encapsulated in the Ecosystem-based Disaster Risk Reduction and Climate Change (Eco-DRR/CCA) paradigm (Fig. 3). The outcome was to develop a framework that promotes wetland resilience with other spinoffs like promoting biodiversity, encouraging sustainable development, promoting sustainable livelihoods and reducing rural poverty.

\section{Disaster Risk Reduction Framework}

Activities and processes to reduce disaster risk are captured in the DRR Framework as indicated in Fig. 4 below. This framework is an international benchmark on DRR and it is important because DRR is one of the three pillars of the proposed framework for wetland management.

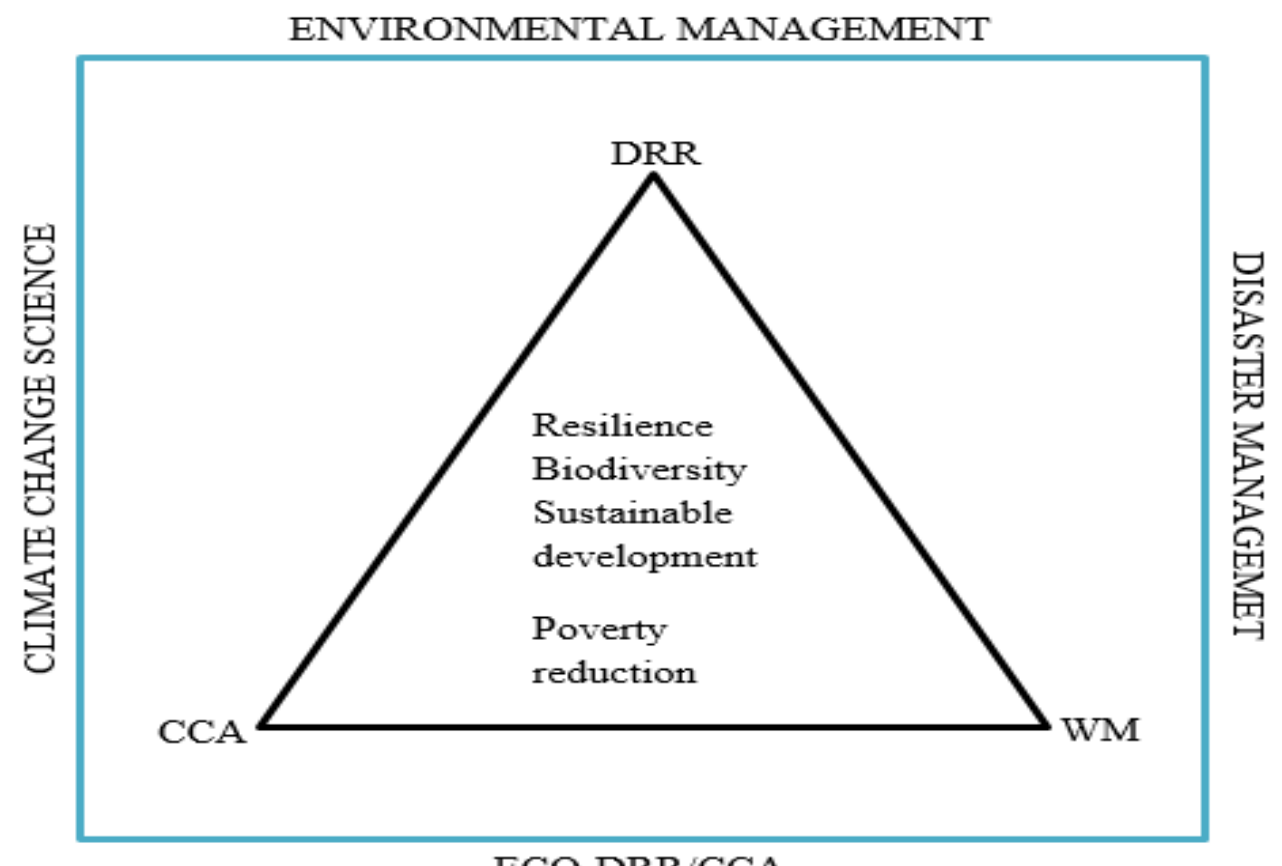

ECO-DRR/CCA

Fig. 3. Conceptual outline of the study, Source: Author's own (2016) 


\section{Sustainable development context}

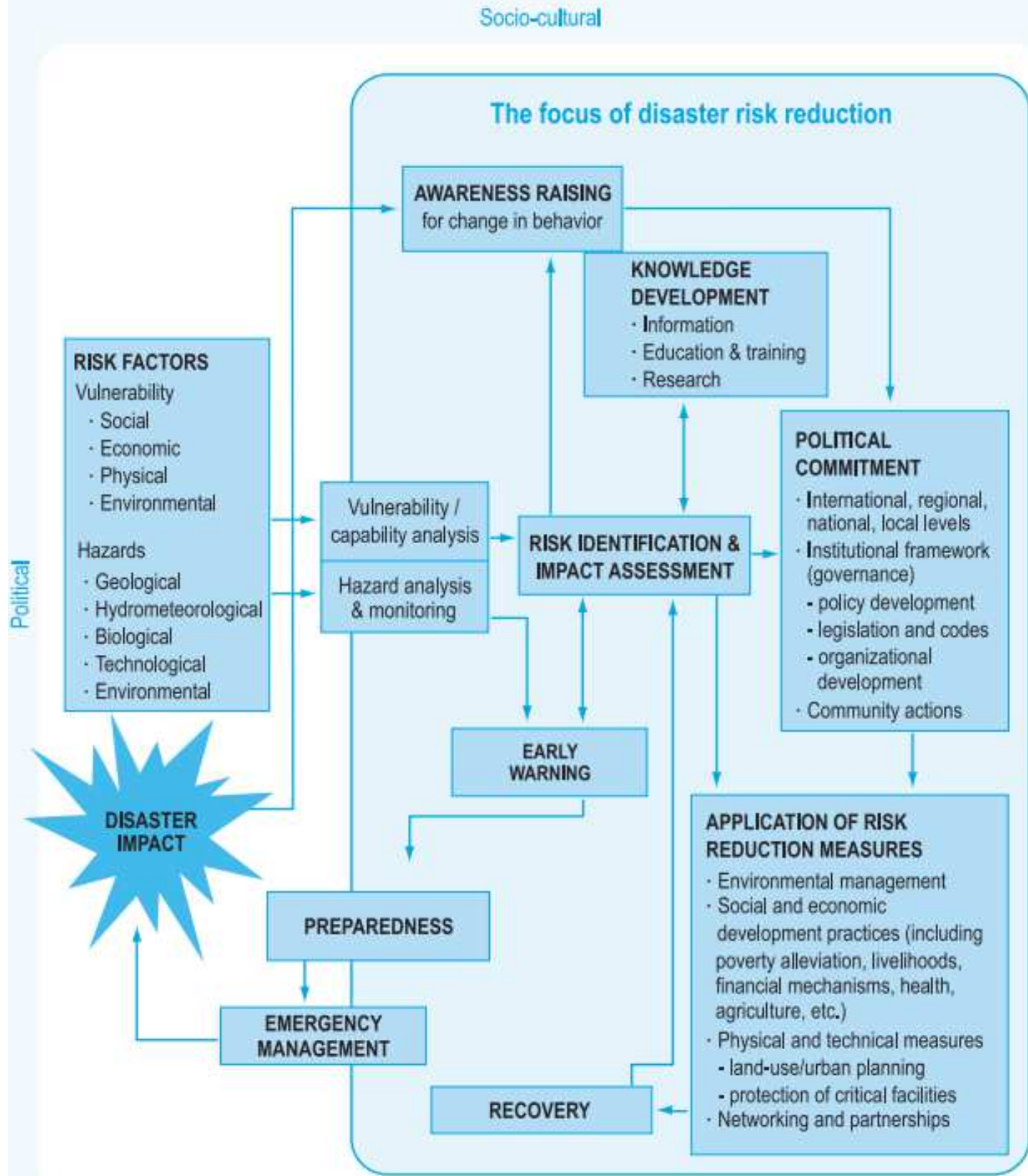

\section{Economic}

Fig. 4. Disaster risk reduction framework, Source: UNISDR $(2004 ; 2015)$

DRR normally begins with evidence-based Risk and Vulnerability Assessment (RVA), but RVA can only be effective if there are good and strong political commitment with effective legislative and institutional arrangement as indicated in the proposed framework. Information from RVA is then used to design various DRR strategies and plans which are then incorporated into development planning to ensure sustainable development. Even during response and recovery to disasters, it is often advised to introduce DRR strategies, for example the Build Back Better concept, which is well-articulated in the new Sendai Framework for Disaster Risk Reduction (SFDR) (UNISDR, 2015). 
The DRR strategies need to be incorporated into wetlands management practices to reduce both natural and man-made shocks that affect wetlands. This will help to improve the ecological status of the wetlands and make them resilient to external shocks. On the other side, resilient wetlands which are in a good ecological state help to reduce disaster risks by acting as buffers. Promoting this cyclical relation is one of the main aims of this paper and is strongly supported in the Eco-DRR/CCA approach.

\section{Climate Change Framework}

The climate change framework illustrates the causes and effects of climate change and the need to manage both the causes and the effects in order to build climate resilient wetlands. Climate change is caused by natural and human subsystem drivers, but more importantly, the human subsystem; hence the term 'anthropogenic climate change' (IPCC, 2007; 2014). The human socioeconomic development has resulted in the emission of more greenhouse gases, especially carbon dioxide that has caused global warming. The latter has resulted in temperature rise, increase in extreme weather events, melting of polar ice and corresponding sea level rise, as well as changes in climatic bands with associated socioeconomic and health effects. Climate change also has diverse effects on ecosystems, such as wetlands (IPCC,
2014). The main solutions to climate change are climate change mitigation and CCA (Fig. 5). The proposed framework focuses on CCA strategies which are often very similar to DRR strategies (UNEP, 2009).

The role of wetlands in CCA to support local resilience, are explored in this study. Some examples of CCA strategies include the concept and practice of "climate-smart conservation" and "green economy."Climate-smart conservation is described by Stein et al. (2014) as "the intentional and deliberate consideration of climate change in natural resource management, realized through adopting forward-looking goals and explicitly linking strategies to key climate impacts and vulnerabilities" (Stein et al., 2014). UNEP (2010) defines Green Economy as one that leads to improvement in human well-being and social equity, while significantly reducing environmental risks and ecological scarcities. Building of natural capital is critical in a Green Economy as a source of public benefits, especially for poor people whose livelihoods and security depend strongly on nature (UNEP, 2010). The link between CCA, Green Economy and wetlands management is that the efficient management and conservation of wetlands is part and parcel of the new concept of Green Economy since it helps to build the stock of natural capital on which many, especially the poor, depend for their livelihoods (UNEP, 2010).

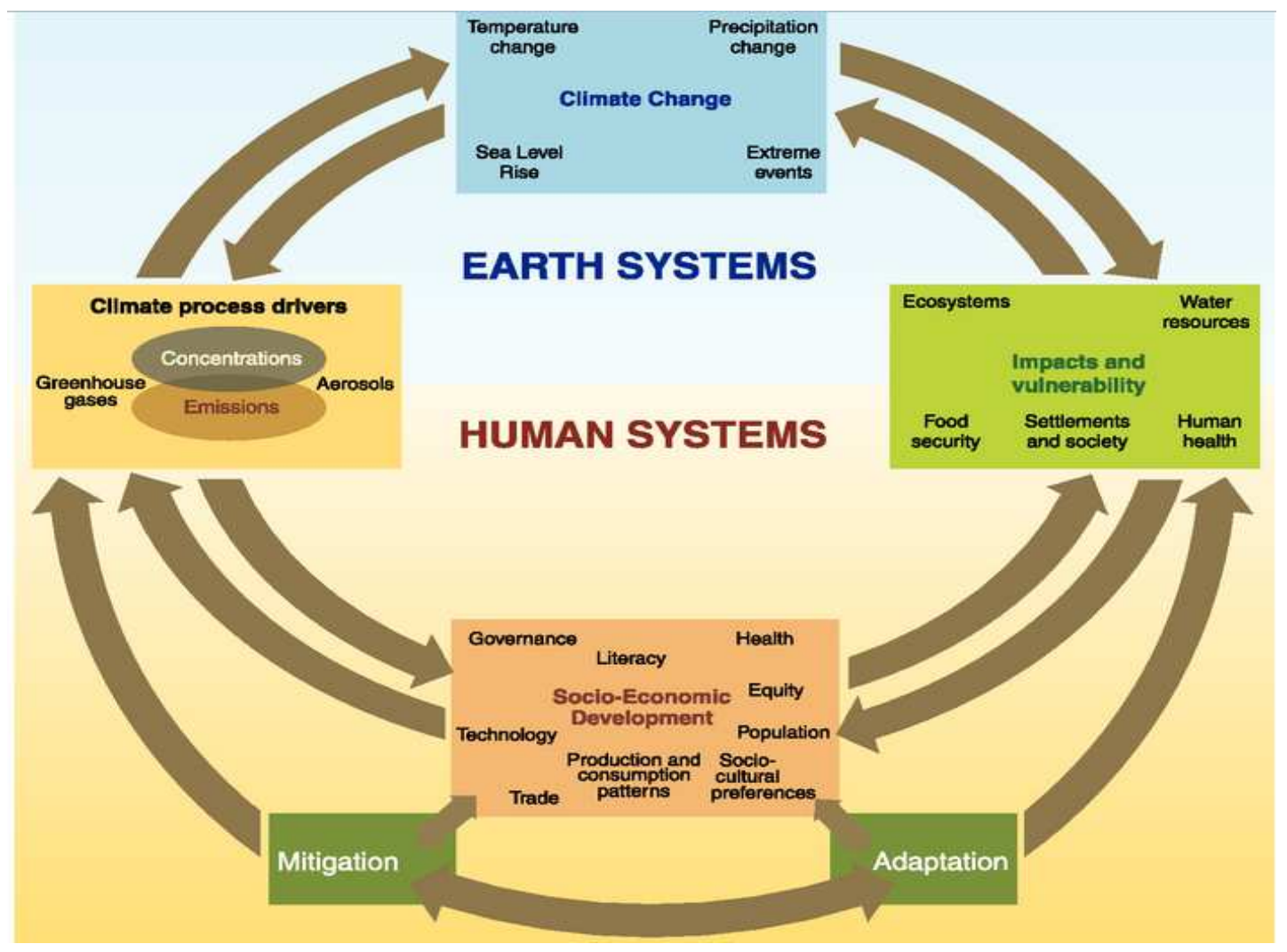

Fig. 5. Schematic framework of anthropogenic climate change drivers, impacts and responses, Source: IPCC (2007) 


\section{The Social-Ecological Model}

Recent environmental management approaches demand innovative research that cuts across traditional disciplinary boundaries and environmental practitioners, scholars and policy-makers alike are increasingly calling for the integration of natural and social sciences to develop new approaches that address the range of complex ecological and societal impacts of modern environmental issues (Virapongse etal., 2016). Effective solutions to environmental problems such as wetlands degradation require the integration of social and natural sciences and the SES framework recognises and addresses this expectation (Virapongse et al., 2016). Social ecology is the study of the interaction between people and their environment (Fabinyi et al., 2014; Turner et al., 2003). It is an analysis of the interactions within the social, institutional and cultural contexts of people-environment relations that make up well-being. Social ecology uses a systemic approach in focusing on the interdependencies of social systems (University of California, Irvine (UCI, 2015). This holistic approach in dealing with complex problems and issues is at the very essence of systems thinking which is adopted in this study.

Social ecology is underpinned by the fact that nearly all our present ecological problems, such as wetland degradation, come from deep-rooted social problems. Present ecological problems can therefore not be clearly understood or resolved without carefully dealing with problems within society (Bookchin, 1993). Many environmentalists pick up ecological problems with the preservation of wildlife, wilderness, or more broadly the planet, but environmental emergencies like the oil spill by an Exxon tanker at Prince William Sound in Alaska or the massive deforestation of redwood trees in California by the Maxxam Corporation all point to the fact that the ecological future of our planet will be decided on social grounds (Bookchin, 1993).

The Centre for Disease Control (CDC) uses a fourlevel social-ecological model to better understand violence and its potential prevention strategies (Fig. 6). Though the model was based on violence prevention, it was replicated in this study for the prevention of wetland degradation in the eastern Free State by simultaneously acting across the multiple levels of the model, namely:

\section{Individual Level}

This first level identifies biological and personal history factors that increase the likelihood of becoming a perpetrator of wetland degradation. Some of the catalyst factors may include age, education, income and history. Prevention strategies to wetland degradation at this level could be designed to promote attitudes, beliefs and behaviours that ultimately prevent wetland degradation. Specific approaches may include education, awareness and life skills training (CDC, 2015).

\section{Relationship Level}

The second level of the model deals with close relationships that may increase the risk of perpetrating; in this case, wetland degradation. A person's closest social circle-peers, partners and family membersinfluences their behaviour and contributes to their range of experience. Prevention strategies at this level may include parenting or family-focused prevention programmes and mentoring and peer programmes designed to reduce negation toward the environment, fostering problem-solving skills and promoting healthy relationships among the people and the environment, such as wetlands (CDC, 2015).

\section{Community Level}

The third level explores the settings, such as schools, workplaces and neighbourhoods, in which social-environment relationships occur and seeks to identify the characteristics of these settings that are associated with perpetrating wetland degradation. Prevention strategies at this level are typically designed to impact the social and physical environment, for example, by reducing social isolation, improving economic and housing opportunities in neighbourhoods, CCA strategies, as well as good policies within schools, community and workplace settings (CDC, 2015).

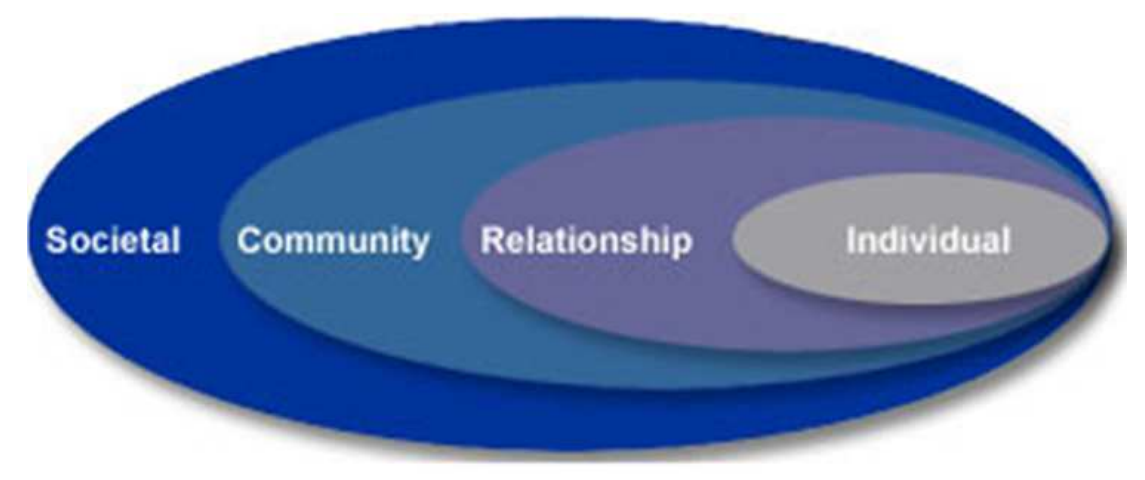

Fig. 6. The social-ecological model, Source: CDC (2015: Online) 


\section{Societal Level}

The fourth and last level of the model looks at the broad societal factors that need to be addressed and which create a climate in which wetland degradation is encouraged or inhibits wetlands conservation. These may include social and cultural norms that support wetland drainage and pollution as an acceptable lifestyle. Other higher-order societal factors may include health, economic, educational and social policies that help to maintain economic or social inequalities between groups in the society (CDC, 2015). The last point supports the location of many informal settlements on communal wetlands in the eastern Free State. Urban expansion and morphology is not haphazard, but is strongly controlled by forces operating within the society, such as land values, zoning ordinances, landscape features, circulation corridors and historical contingencies such as apartheid in South Africa. The apartheid situation in South Africa has to an extent led to informal settlements in most communal wetlands as many blacks were denied access to dry arable land.

Well-managed human-environment interdependence contributes to building social-ecological resilience and through the resilience approach strengthens sustainable development through goods and services that flow from the resilient system such as wetland (Takeuchi et al., 2014). The social-ecological system model is important in this study to guide the development of a harmonious relationship between humans (the local community) and their environment (the wetlands).

\section{Community Capital Framework (CCF)}

Community Capitals Framework (CCF) is increasingly used by researcher to carry out community vulnerability analysis, resilience and development from a system perspective (Mattos, 2015; Peters, 2016). First developed by Flora et al. (2003), this framework examines seven community capitals which include natural, financial, social, political, cultural, human and built capital (Mattos, 2015). Jordaan (2017) added the institutional capital which then increases the number of community capitals to eight. Capital is human created asset that is invested to create new resources without consuming the entire asset (Peters, 2016). Though the term "community capital" is used, it could also mean community assets as some capital like the natural capital is not often created but an endowment to the community. Figure 7 below shows the various community capitals.

The various capital are interrelated and their availability increases community resilience while the shortage or absence of these capital increase community vulnerability to shocks. Table 2 summarises these capitals and how they contribute to community resilience.

This paper examines wetlands as a form of natural capital and proposes a framework for holistic wetland management that would improve wetlands resilience. Well-functioning and resilient wetlandsbetter reduce disaster risks and adapt to climate change.

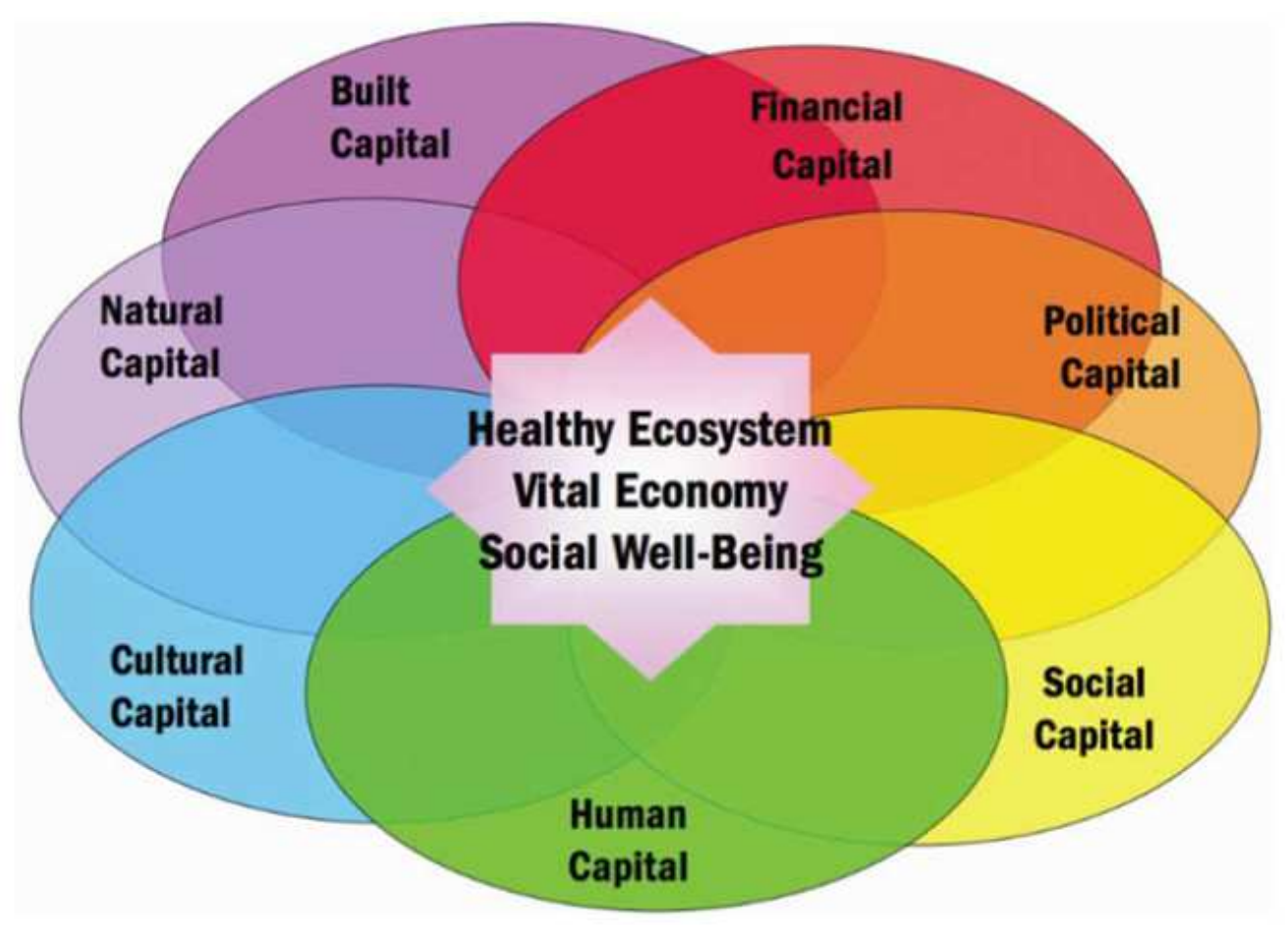

Fig. 7. Community capitals framework, (Source Peters, 2016) 
Table 2. Using the capital framework to build resilience

\begin{tabular}{llll}
\hline Form of capital & Definition & Indicator & How it contribute to resilience \\
\hline Natural & They are environmental/ecological & Air quality, land, water and & $\begin{array}{l}\text { Forms the base upon which other } \\
\text { capitals are generated; sustains }\end{array}$ \\
& $\begin{array}{l}\text { water that a community is endowed } \\
\text { are considered as a form of natural } \\
\text { capital. Other forms of natural capital } \\
\text { include ecosystems like the forest, }\end{array}$ & $\begin{array}{l}\text { biodiversity, scenery, topography, } \\
\text { location (proximity) }\end{array}$ & $\begin{array}{l}\text { all forms of life; provide } \\
\text { livelihoods; provide protection } \\
\text { against hazards; regulate climate; } \\
\text { protects the environment etc }\end{array}$
\end{tabular}

Financial Financial resources available to invest in community capacitybuilding, underwrite businesses development, support civic and social entrepreneurship and accumulate wealth for future community development

Income, savings, investment, livelihoods, Tax burden/savings, philanthropic donations, grants, contracts, regulatory exemption, investments, loans, poverty rates

Trust, norms of reciprocity, network structure, group membership, cooperation, sympathy, attachment, common vision and goals, leadership, depersonalization of policies, acceptance of alternative views, diverse representation Housing, public facilities, critical infrastructure, telecommunications, industrial parks, main streets, water and sewer systems, roads, etc Population, education, skills, health, creativity, youth, diverse groups, information, knowledge

Work ethics, respect (gender, laws), beliefs, ethnic festivals, multi-lingual population, traditions, heritage, or a strong work ethic Well-equipped and functional DMCs, institutions for joint cooperation, DM policies, environmental and climate policies, building codes, DRM plans, good governance, level of corruption etc
Used to create human capital and (education and skills) built capital (machines, technology, structures) and even additional financial capital through higher wages, higher profits, or more sales Increases capacity e.g. Insurance Speeds up recovery process, Increases wellbeing and reduces poverty, Boost confidence, power and esteem Facilitates coordination and cooperation, facilitates access to resources cushion against shocks

Support the creation of other capitals

Increases knowledge and skill to understand community risks, Increases ability to develop and implement risk reduction strategy; education, training, experience and good health contribute to the development of human capital Facilitates communication and transportation, facilitates evacuation increases a culture of safety

Determine capabilities to respond to emergencies

Creates the enabling environment under which other capitals are built regulations and their enforcement. It shows access to power and power brokers, effective and good policies and governance

(Source adapted from Mattos, 2015; Peters, 2016; Jordaan, 2017)

\section{Data Collection}

Data were collected between June 2014 and March 2016 using semi-structured questionnaires administered to 176 wetland owners and users. Of the 176 respondents, 93 were from eight different communal wetlands and 83 were private wetland owners and managers (including three wetlands in protected areas) spread evenly over the study area. The questionnaires were the main data collection tool and questions in the questionnaires included both closed and open-ended questions. The questionnaires covered aspects of wetlands such as the risk and vulnerability of 
wetlands including major environmental hazards in the study area, the ecological status of wetlands, functions of wetlands in the area, planning and managing wetlands for disaster risk reduction and climate change adaption as well as ways of building wetlands resilience in the study area. Though most of the wetlands were found in private commercial farms, the communal and government protected wetlands were also examined in order to determine if there were any observable trends based on the type of wetlands ownership and use.

Interviews were also conducted with 30 specialists comprising climate change scientists $(n=15)$, disaster and environmental managers $(\mathrm{n}=8)$, wetland specialists $(n=5)$ and environmental law specialists $(n=2)$. The interviews were to solicitude expert knowledge inputs on various aspects related to wetlands and the collected data were analysed in emerging themes.

Field observation was carried out in 21 wetlands (11 privately owned, seven communally owned and three wetlands in protected areas controlled by the government). During the field observation, a field data sheet consisting of ten wetland parameters adapted from Oberholster et al. (2014) was used. The aggregation of the scoring of these parameters gave an indication of the level of vulnerability and adaptive capacities of the observed wetlands. Lastly rainfall and temperature records for at least the past 30 years from weather stations located within the study area were obtained from the South Africa Weather Service (SAWS) in keeping with international norm (Arbogast, 2011; IPCC, 2007; Reynolds et al., 2015; Strahler and Strahler, 2005). The use of triangulation (Burns and Grove, 2005; Rakotsoane and Rakotsoane, 2006) together with a pilot study of six wetlands backed by the administration of same questionnaire to the respondents added validity and reliability to the collected data. The data were analysed using the SPSS and presented in the form of tables, diagrams and photos. The Kendall's W Test was performed to explore private wetland owners' perception of current and future threats and wetland management practices.

\section{Results and Discussion}

\section{Wetland Ownership}

Most of the wetlands were privately owned (63.9\%) in commercial farms, then those owned by the government (28.9\%)in protected areas such as Seekoeivlei, Golden Gate wetlands and Braamhoek (or Ingula) wetland and lastly those that were communally owned (4.8\%) and used mainly for communal grazing.

\section{Value and Ecological Services Provided by Wetlands}

The Millennium Ecosystem Assessment (2005) grouped wetland ecological services into four broad categories, which include provisioning, regulating, cultural and support services. Responses from the questionnaires and field observation revealed that grazing and food production dominated the benefits from the category of provisioning services. Erosion and natural hazard regulations were dominant in the regulatory category, while educational and aesthetic services dominated the cultural category. Soil formation and nutrient cycling completed the support services category (Table 3 ).

Table 3. The reported major benefits from wetlands in privately owned land

\begin{tabular}{|c|c|c|c|c|c|}
\hline Services & No benefit & Little benefit & Important benefit & Very important benefit & Ratings \\
\hline \multicolumn{6}{|l|}{ Provisioning } \\
\hline Grazing & 10 & 15 & 27 & 31 & $2.95^{1 \mathrm{st}}$ \\
\hline Fresh water & 18 & 11 & 19 & 35 & $2.86^{2 n d}$ \\
\hline Food & 46 & 19 & 9 & 9 & $1.77^{3 \mathrm{rd}}$ \\
\hline Fibre and fuel & 48 & 22 & 7 & 6 & $1.65^{4 \mathrm{th}}$ \\
\hline Biochemical & 52 & 18 & 6 & 7 & $1.61^{5 \mathrm{th}}$ \\
\hline Genetic materials & 58 & 13 & 6 & 6 & $1.52^{6 \text { th }}$ \\
\hline \multicolumn{6}{|l|}{ Regulating } \\
\hline Erosion regulation & 10 & 10 & 23 & 40 & $3.12^{1 \mathrm{st}}$ \\
\hline Natural hazard regulation & 8 & 14 & 24 & 37 & $3.08^{2 n d}$ \\
\hline Water regulation & 10 & 11 & 25 & 37 & $3.07^{3 \mathrm{rd}}$ \\
\hline $\begin{array}{l}\text { Water purification and } \\
\text { waste treatment retention }\end{array}$ & 10 & 15 & 25 & 33 & $2.98^{4 \text { th }}$ \\
\hline Pollination & 8 & 22 & 25 & 28 & $2.88^{5 \mathrm{th}}$ \\
\hline Climate regulation & 27 & 20 & 18 & 18 & $2.33^{\text {th }}$ \\
\hline \multicolumn{6}{|l|}{ Cultural } \\
\hline Educational & 21 & 13 & 18 & 31 & $2.71^{1 \mathrm{st}}$ \\
\hline Aesthetic & 19 & 25 & 18 & 21 & $2.49^{2 \text { nd }}$ \\
\hline Recreational & 35 & 16 & 19 & 13 & $2.12^{3 \mathrm{rd}}$ \\
\hline Spiritual and inspirational & 39 & 22 & 17 & 5 & $1.86^{\text {th }}$ \\
\hline \multicolumn{6}{|l|}{ Supporting } \\
\hline Soil formation & 13 & 14 & 22 & 34 & $2.93^{1 \mathrm{st}}$ \\
\hline Nutrients cycling & 15 & 14 & 24 & 30 & $2.83^{2 n d}$ \\
\hline
\end{tabular}


Table 4. The economic value of wetland resources in Uganda

\begin{tabular}{lll}
\hline & & Estimated value in \\
No. & Wetlands service & 4240000 \\
\hline 1 & livestock pastures & 34000000 \\
2 & water for livestock consumption & 13900000 \\
3 & domestic water supply & 1220000 \\
4 & gross annual value added to milk production & 4630000 \\
5 & papyrus raw materials & 11500000 \\
6 & value added to papyrus to produce mat & 8650000 \\
7 & grass for mulching & 7100000 \\
8 & non-use value (water recharge and regulation) & 1700000000 \\
9 & flood control & 1091444 \\
10 & fish breeding/spawning and availability & 417536 to 25090000 \\
11 & crop farming & 48668 \\
12 & wetland management costs for 2011/2012 financial year & 1400000 to 6610000 \\
13 & opportunity costs for limiting access to wetlands or stopping local & \\
14 & communities from using wetlands & 48.24 per hectare \\
15 & average benefit for maintaining biodiversity in wetlands & 10.491 per hectare \\
\hline
\end{tabular}

Source: Adapted from Kakuru et al. (2013)

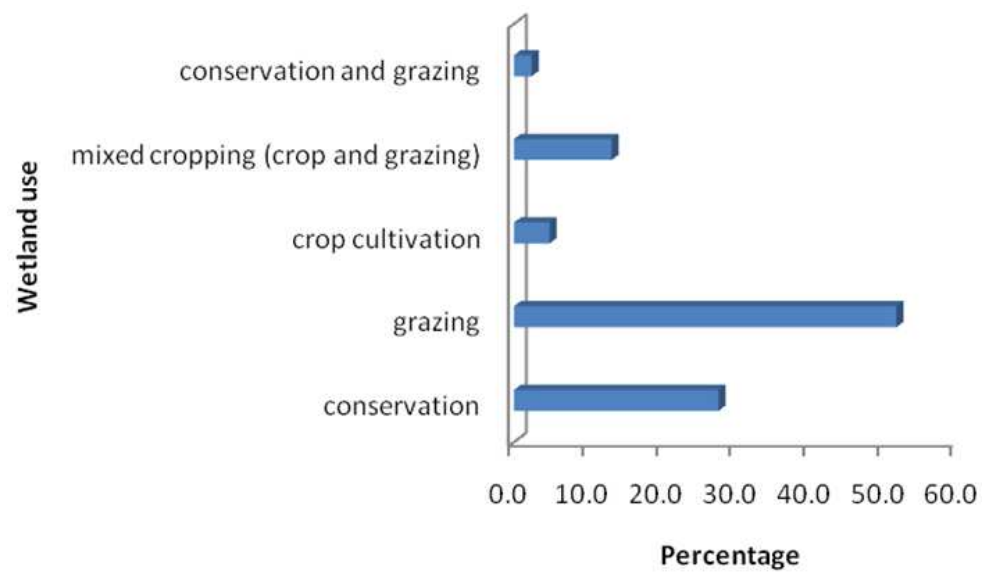

Fig. 8. Dominant use of private wetlands in the eastern Free State, Source: Author's own (2016)

Results showed that most of the wetlands in the study area (about 70\%) were used for farming, main lygrazing and a few for crop cultivation (Fig. 8) while the rest was used for conservation which comprised about $30 \%$ of private wetland use.

Wetlands in South Africa (including the eastern Free State) like in the rest of the world provide varied and vital ecological services, which are often undervalued and ignorantly unappreciated (Dini, 2004; TEEB, 2010). This has led to the degradation and conversion of many wetlands without proper cost benefit analyses (Tietenberg and Lewis, 2012).

Table 4 based on a study in Uganda demonstrates that the livelihoods of the local communities are highly dependent on wetlands, that the benefits of an effective and efficient management of wetlands for improved ecological services outweigh the cost of doing so. That wetlands contribute significantly to food security and lastly, but most importantly, the study justifies the 'wise use' (for example for spawning and papyrus harvesting) and conservation of wetlands in Uganda.

\section{Wetland Vulnerability}

Vulnerability of any community or system is the product of exposure to hazards and the lack of coping or adaptive capacities (Wisner et al., 2004; Coppola, 2011). Any risk reduction measure should focus on reducing vulnerability and improving coping/adaptive capacities. Wetlands in the study area, as in many parts of the world, are affected by both natural and anthropogenic or man-made hazards. The main hazards reported in communal wetlands $(\mathrm{n}=93)$ included flood $(66.7 \%)$, veld fires (29\%) and drought (15.1\%). Ignorance about the functions and values of wetlands as well as poorly functioning legal and institutional arrangements were contributing factors to wetlands vulnerability in the area and all these often result in wetland degradation or lost through conversion to other land uses. 
In privately owned wetlands, respondents (n-63) agreed that floods, droughts and veld fires (75.6\%) were becoming more frequent. This data was collected before the 2014-2016 drought reported as the worst drought in the past 50 years in the study area and the entire southern Africa (Jordaan, 2017).

Private wetland owners' perception of current and future threats on wetlands is given in Table 5. Top in the ranking was the lack of awareness on wetland benefits, followed by uncontrolled fires and then overgrazing, with 93\% agreeing to the ranking order (Table 6). The Chi-square statistic of 92.91 was highly significant at $1 \%$ level, suggesting that the ranking was valid and efficiently estimated. This further shows that the individual threats identified in the study jointly and significantly explain the actual threats to wetlands in the eastern Free State.

Private wetland owners' suggestions on better wetland management practices is given in Table 7 . Education, training and awareness creation were the top suggested practices.

The type of ownership in a way dictated the ecological status of the wetland as observed in the field. While most wetlands in protected areas were in good to excellent ecological state, privately owned wetlands were in average to good state but the communally owned wetlands were generally in a very poor state. The state of the wetland had a positive relationship with the management style. Protected wetlands had management plans that were constantly revised and updated with monitoring mechanisms. This was not the case with wetlands in private and communal ownership. Private owners had no management plans, but used their experience and education to manage their wetland. Most private owners (77.1\%) had used their wetland for more than five years and $60 \%$ had more than 10 years' experience on wetland issues. Additionally, private owners had better levels of education, $71 \%$ had a minimum undergraduate qualification. On the other hand communal wetlands had no management plans, generally had a low level of education with $82.3 \%$ never receiving any form of education. There was no accountability and no control in the grazing pattern of communal wetlands, hence most of these wetlands were overgrazed and degraded (Fig. 9).

Given the seasonal nature of the wetlands in the eastern Free State and that most of the wetlands were used for grazing (both livestock and wildlife), it was important to examine the seasonal management plans for wetlands in the area. Grazing management in wetlands is complex, often site-specific, depends on the type of wetland, its soils and its degree of wetness (Kotze et al., 2009; Gray et al., 2013). Very wet wetlands may have a low grazing capacity in summer simply because they are inundated. Many animals in a very wet wetland may also cause poaching. The wetlands in the study area are particularly valuable for winter grazing, because it is a sour-veld area, i.e., the nutritional value of the vegetation is very low in the winter, especially the protein content.
Table 5. Common risks in communal wetlands

\begin{tabular}{llll}
\hline Hazard & Responses & Frequency & Percentage \\
\hline Floods & No & 31 & 33.3 \\
& Yes & 62 & 66.7 \\
Droughts & No & 79 & 84.9 \\
& Yes & 14 & 15.1 \\
Fires & No & 66 & 71.0 \\
& Yes & 27 & 29.0 \\
\hline
\end{tabular}

Table 6 . Perceived wetlands threats by private wetland users

Kendall's w test

\begin{tabular}{ll} 
Threat & Mean rank \\
\hline Lack of awareness on wetland benefits & $8.94^{1 \mathrm{st}}$ \\
Uncontrolled fire & $8.81^{\text {2nd }}$ \\
Overgrazing & $7.64^{\text {3rd }}$ \\
Upper catchment management activities & $7.28^{\text {th }}$ \\
Sedimentation & 7.23 \\
Lack of material resources to manage & 7.14 \\
Soil erosion & 6.96 \\
Lack of human management capacity & 6.70 \\
Change in water regime & 6.45 \\
Invasive alien species & 6.19 \\
Pollution & 6.12 \\
Conversion to other uses & 5.87 \\
Climate variability & 5.65 \\
\hline Test statistics: & $83 ;$ Kent
\end{tabular}

Test statistics: N 83; Kendall's W $W^{\mathrm{a}}$ 0.93; Chi-square 92.91; df 12; Asymp. Sig. 0.000

Table 7. Suggested activities that will lead to better wetland management in the area

Kendall's w test

\begin{tabular}{ll}
\hline Ranks & Mean rank \\
\hline Education and training on wetlands & $6.99^{1 \mathrm{st}}$ \\
Awareness creation on wetland & $6.22^{2 \mathrm{nd}}$ \\
functions and values & \\
Good coordination amongst & $6.08^{3 \mathrm{rd}}$ \\
wetland stakeholders & \\
Fencing of wetlands & $6.08^{4 \mathrm{th}}$ \\
Effective law enforcement & 5.87 \\
Avoid settlement within wetlands & 5.87 \\
Avoid overgrazing & 5.80 \\
Avoid wetland pollution & 5.73 \\
Rehabilitation of degraded wetlands & 5.73 \\
Better management with & 5.94 \\
management plans & \\
Control veld fires & 5.66
\end{tabular}

Test statistics, N 79, Kendall's W ${ }^{\mathrm{a}}$ 0.064, Chi-square 50.954, df 10, Asymp. Sig. 0.000

This is a form of adaptation of the vegetation to the high fire frequencies in the area where the plants therefore transport their nutrients and energy to the roots for regrowth in the spring (Fig. 10). However, wetlands on the other hand maintain higher nutrient and protein levels as compared to the dryland sour vegetation and are therefore valuable winter grazing areas (Kotze et al., 2009). 


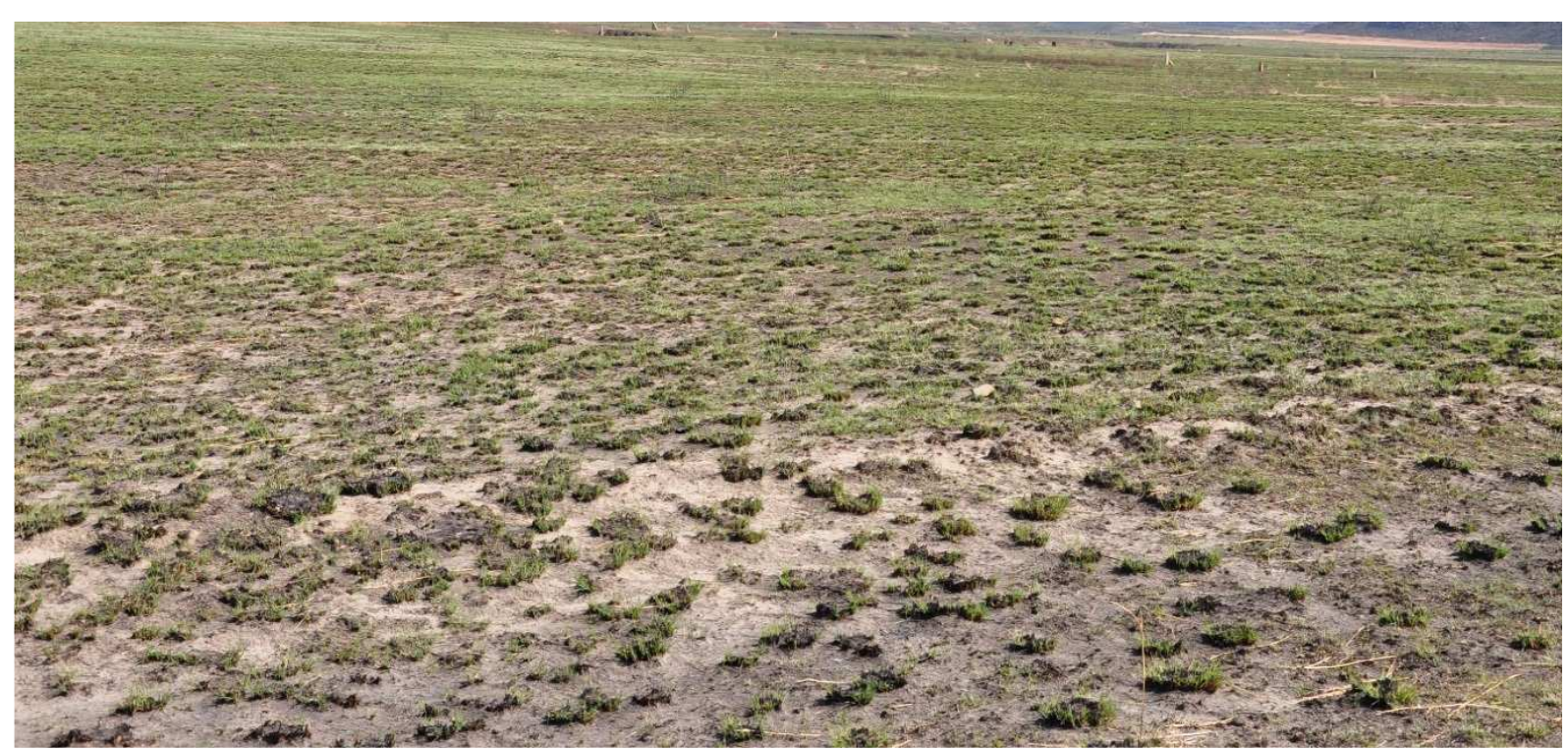

Fig. 9. An example of an overgrazed wetland in the study area, showing spaces with no grass cover, Source: Author's own (2016)

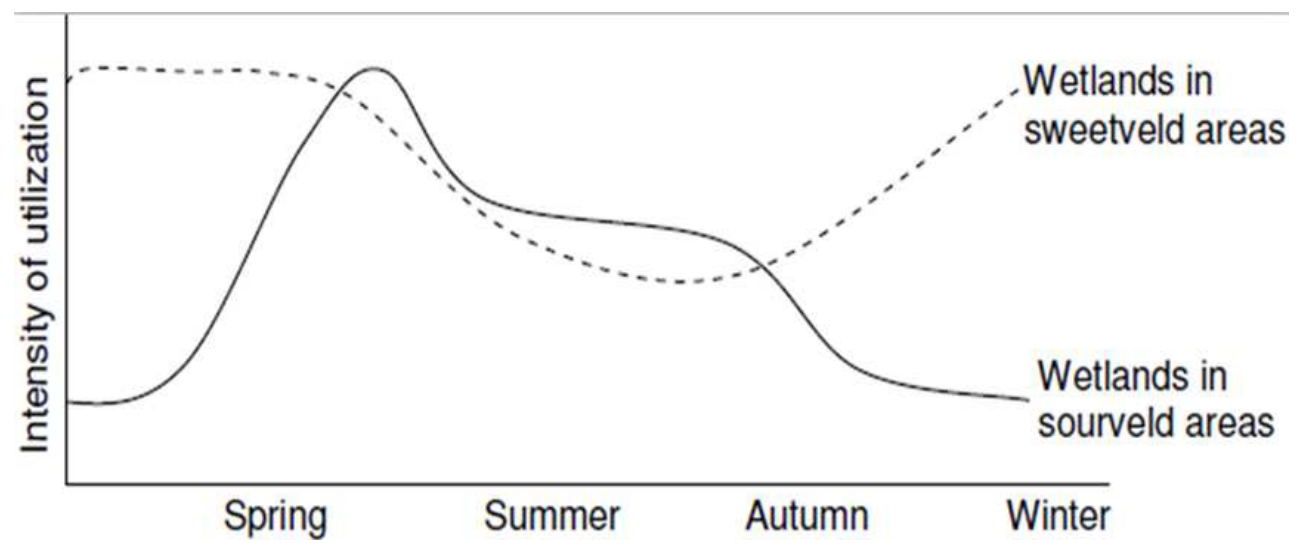

Fig. 10. Suggested intensity of seasonal grazing in sweetveld and sourveld areas for summer rainfall conditions such as in the eastern Free State, Source: Kotze et al. (2009)

\section{Fire as a Wetlands Management Tool}

Fire was identified as one of the major hazards in the study area, but it could also be used as a good wetland management tool if properly executed. While it is recommended to burn wetlands after three to five years to reduce the fuel load (moribund), it is important to consider the type of burning and the seasonal timing of the burning. Both root burns and cover burns were observed in the study area. Root burns kill roots without consuming soil, occur when there is little or no water over the soil surface, there is an abundant fuel load and the fire is slow-moving (Gray et al., 2013). Root burns may not be good as it may reduce the richness of wetland plants in the study area. Cover burns on the other hand remove above-ground biomass without killing roots or harming soils and occur when there is high soil moisture or when the soil surface is flooded a few centimetres deep (Gray et al., 2013). Parts of emergent plants are then burned, but the soil and roots remain intact. Plants can then quickly recover from cover burns if plant stubbles are not subsequently covered by flood water (Gray et al., 2013). Cover burns were observed as a good approach in the eastern Free State. Wetlands were also used to construct effective firebreaks in the study area (Fig. 11). Properly planned and executed firebreaks on wetlands are good mitigation measures against runaway fires. More education and training is needed on when to burn, because cases of burning during red and yellow days (days with a high fire index) were observed and often reported in the study area especially in the Maluti-a-Phofung. Local 
municipality which is a hot spot for veld fires in the entire Free State province. Some farmers, especially the emerging and communal farmers, did not belong to any Fire Protection Associations (FPA), which can be a strong social capital and a cushioning mechanism during veld fire shocks.

\section{Managing Wetlands for Disaster Risk Reduction and Climate Change Adaptation}

Disaster risk reduction and climate change adaptation measures are part and parcel of resilience building. All 15 climate change experts who completed the survey on climate change agreed that the eastern Free State climate has changed over the years. Some mentioned more frequent droughts, rise in temperature, change in rainfall patterns, change in the timing of the seasons, decrease in crop yield and even political discussions on climate change as evidences to support climate change in the area. The ideas expressed by these respondents correlate very well with those from literature review (IPCC, 2007; 2014; UNFCCC, 2015).

The climate change experts also pointed out that climate change would affect wetland hydrology in the study area, given the fact that rainfall was persistently recorded to be below normal, temperatures were rising, accompanied by higher evaporation and therefore affecting the recharge of wetlands. They further commented that these climatic changes would put much stress on wetlands aquatic species. The various IPCC reports and other literature on climate change support the above arguments (Gitay et al., 2011; Grundling, 2012; IPCC, 2007; 2014).

The secondary weather data analysis on two key climate factors of temperature and rainfall for over three decades in the study area showed high annual variability trends in both temperature and rainfall, but failed to show any clear shift in these climate parameters. It is important to plan and manage wetlands in recognition of high climatic variability as a measure to build wetland resilience. Research shows that communitybased natural resource management contributes to enhancing resilience by conferring social and ecological benefits to individuals, their community and to the environment and to reducing vulnerability (Takeuchi et al., 2014; Tidball and Krasny, 2014).

The study also found that the sampled community, especially those using communal wetlands, had little or no knowledge about climate change and the role that wetlands could play to mitigate and adapt to the impacts of climate change. The management of wetlands for disaster risk reduction and climate change adaption is gaining global attention and is well-encapsulated in the new approach of Ecosystem-based Disaster Risk Reduction / Climate Change Adaptation (Estrella and Saalismaa, 2011; CNRD/PEDRR, 2013; Costanza et al., 2014; Dudley et al., 2015; PEDRR, 2013; Gupta and Nair, 2012; Renaud et al., 2013; UNEP, 2009).

The role and linkages between ecosystems such as wetlands, disaster risk reduction and climate change adaptation is summarised in Fig. 12.

There are more similarities than there are differences between DRR and CCA as both have common concerns in managing climate-related risks, share a common goal of reducing vulnerability and achieving sustainable development. Both use common concepts in understanding the components of risk and both are increasingly being integrated into interdisciplinary research on DRR and CCA. (Doswald and Estrella, 2015; IFRC, 2013; Mitchell and Van Aalst, 2008; Thomalla et al., 2006).

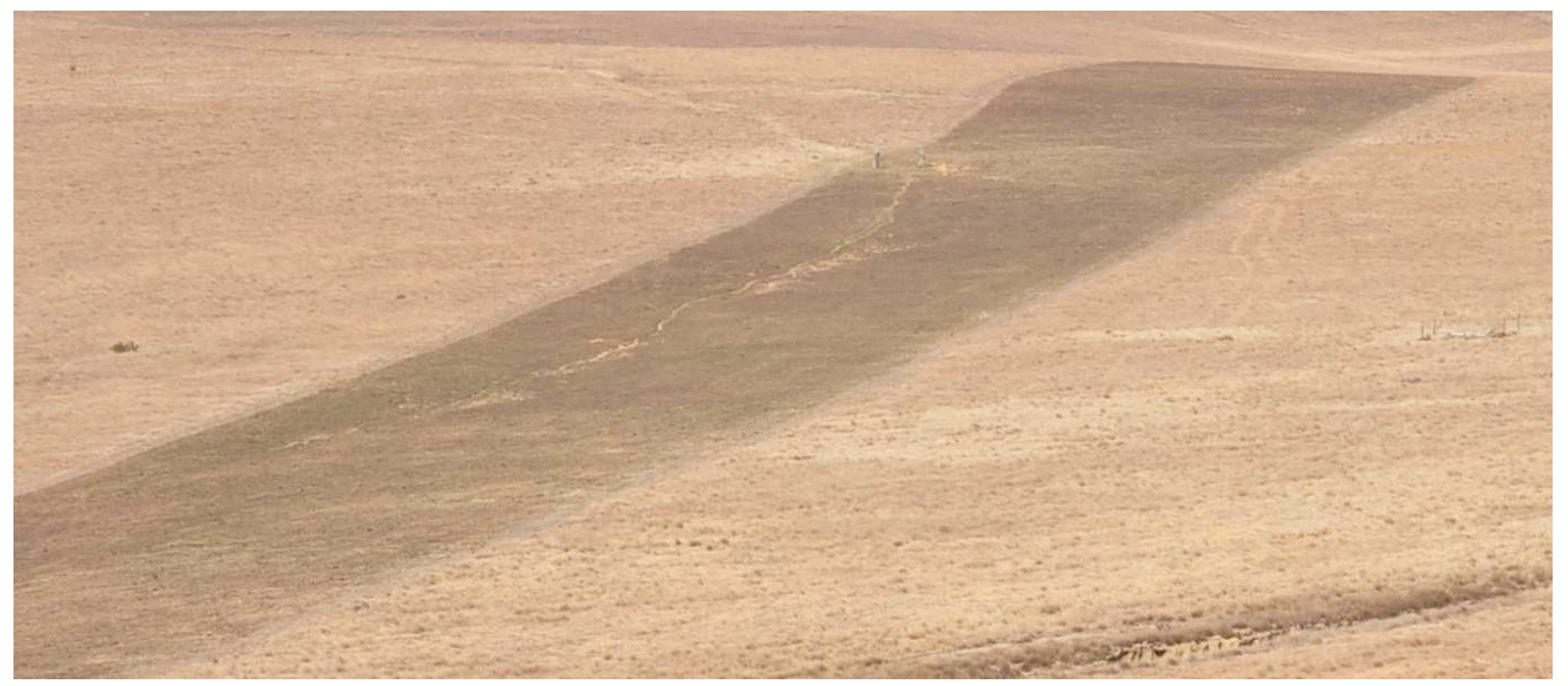

Fig. 11. Wetlands used as effective fire breaks, Source: Author (2016) 


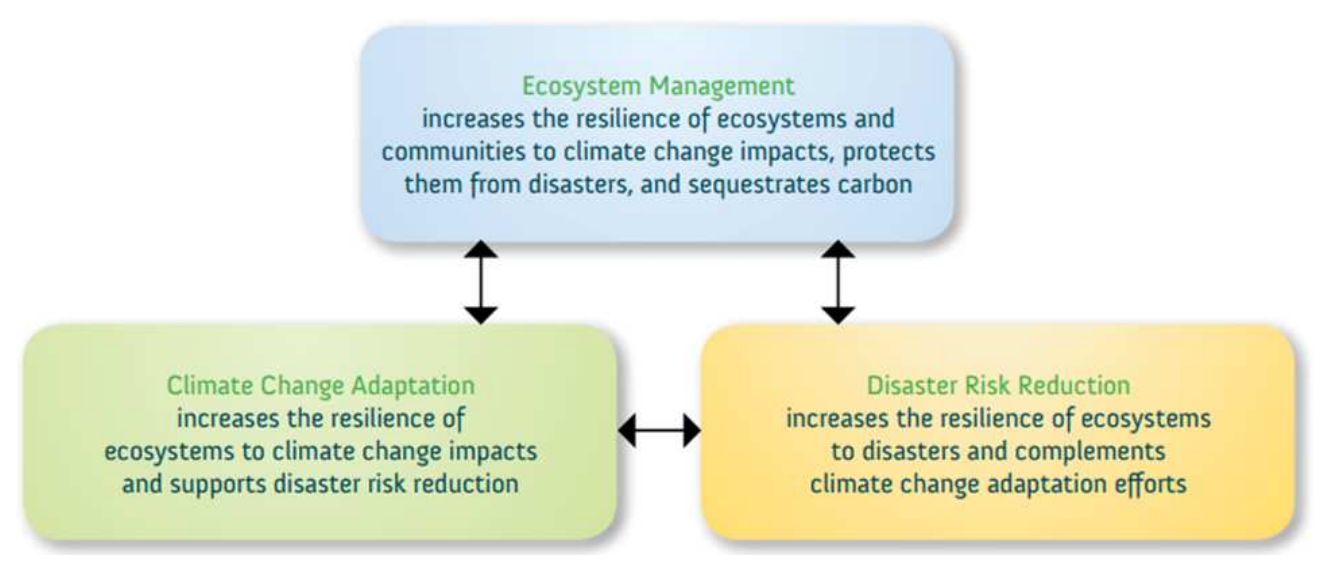

Fig. 12. The role of sustainable ecosystem management in disaster risk reduction and climate change adaptation, Source: UNEP (2009)

Healthy wetlands can reduce disasters by influencing hazards, exposure, vulnerability and providing livelihoods and building resilience (PEDRR, 2014; Renaud et al., 2013; UNIDRS, 2013). For example, the value of wetlands in terms of annual flood damages avoided in the city of Vientiane in the Lao People's Democratic Republic, was estimated at US\$ 5 million. The impact of the Indian Ocean tsunami of 2004 was highly dissipated and its impacts reduced in coastal areas which had healthy well-functioning ecosystems such as coastal mangroves (UNISDR, 2013).

Eco-engineering like maintaining healthy wetlands has proven to be more cost-effective than structural engineering in mitigating disasters (PEDRR, 2013). For example, in Vietnam an estimated US\$ 1.1 million was spent planting mangroves which saved an estimated US\$ 7.3 million in annual dyke maintenance (TEEB, 2010). The Netherlands learnt from the 1953 floods and the extreme high river tides of the 1990s that structural engineering alone was no longer an adequate solution to their flood problems. The Dutch adopted the 'Living with Water' approach whereby large river channels were opened and healthy wetlands maintained (Dione, 2014). The UNEP and the EU are currently implementing ecosystem-based approaches for DRR (Eco-DRR) with demonstration projects in Afghanistan, Haiti, Democratic Republic of the Congo and Sudan (Renaud et al., 2013). The aim of these Eco-DRR projects is to improve ecosystems management in order to enhance their regulatory and provisioning services for risk reduction, demonstrate the cost-effectiveness of ecosystem-based approaches and boost local and national capacities to integrate Eco-DRR in national and local development planning (UNISDR, 2015).

The Great East Japan Earthquake and Tsunami of 2011 demonstrated that disaster mitigation based solely on grey infrastructure and engineering is insufficient in the long term. The Japanese thus adopted both engineering resilience and ecological resilience to mitigate disasters which are becoming more complex and occur under a changing climate (Suppasri et al., 2013; Takeuchi et al., 2014).

In April 2007, the United States Environmental Protection Agency did a green-grey comparison for the purification of the City of New York, drinking water from the Catskill Mountains and found out that by investing $\$ 300$ million over ten years in green infrastructure (maintaining healthy forests and reserved areas such as wetlands), the city could save the building of a water filtration plant that cost $\$ 8$ billion. Meanwhile the City of Philadelphia found that the net present value of green infrastructure such as maintaining healthy wetlands for storm water control ranged from $\$ 1.94$ to $\$ 4.45$ billion, compared to only $\$ 0.06$ to $\$ 0.14$ billion for conventional grey infrastructure over a 40 -year period. Using wetlands, it could cost North Carolina 47 cents per thousand gallons of treated storm water run-off, compared to $\$ 3.24$ per thousand gallons for the conventional grey option (NSTC, 2015; Talberth et al., 2013).

\section{Building Wetlands Resilience}

Wetlands need to be resilient in order for them to provide an effective and efficient ecological service. Twigg (2009) views community or system resilience as the capacity to anticipate, minimise and absorb potential stresses or destructive forces. The community can adapt or resist, manage or maintain certain basic functions and structures during disastrous events and recover or 'bounce back' after an event (Twigg, 2009). In social-ecological systems, resilience is the ability of a social-ecological system such as a wetland to maintain its functionality when hit by a shock, or maintain the basic characteristics needed to renew or reorganise itself if a large stressor seriously alters its structure and function (Walker et al., 2002; Takeuchi et al., 2014).

Resilience is not a static state but resilient systems and communities often display dynamism in response to shocks that start with surviving, then move to adapting and lastly to transforming in order to maintain basic structures and functions (RSS, 2014). See Fig. 13 below. 


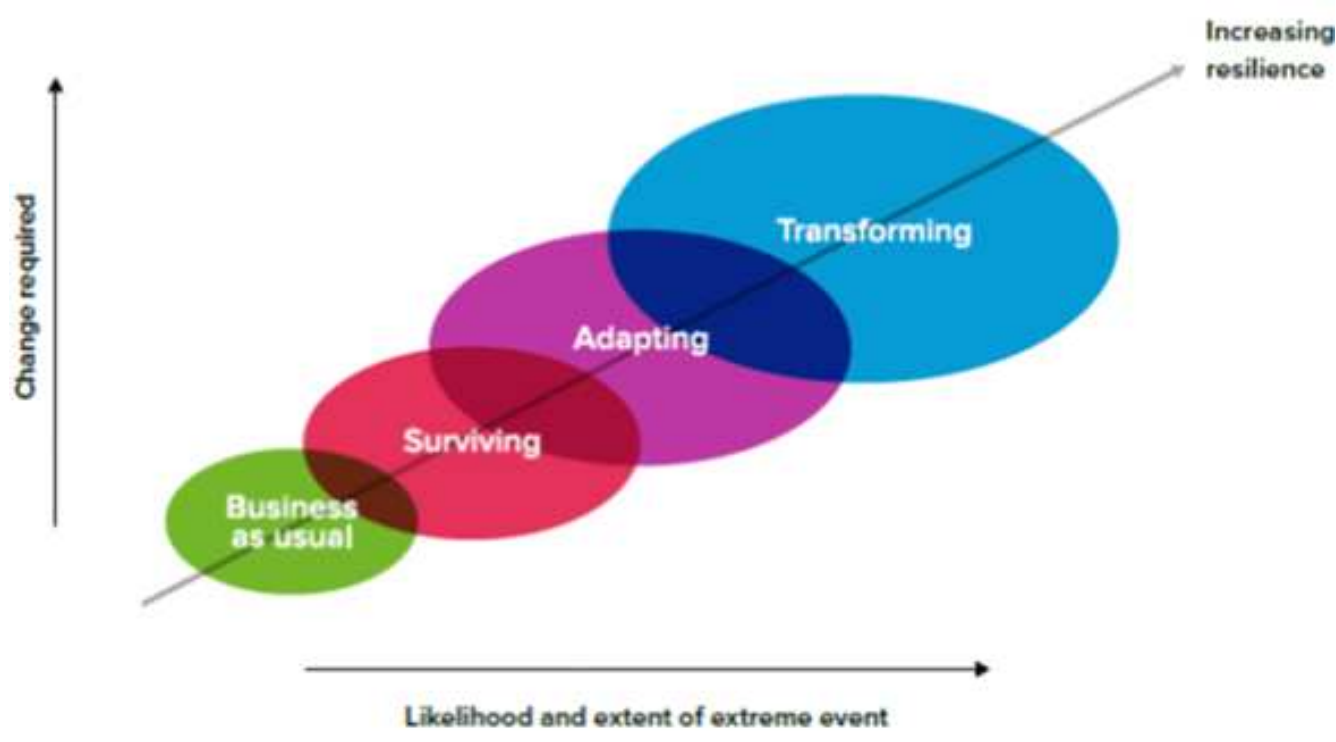

Fig. 13. Components and progress of resilience, Source RSS, 2014

Resilience, vulnerability, disaster risk reduction and adaptation are inter-related concepts though their mutual relationships are still not well-documented (Lei et al., 2014). These concepts are common in environmental management, climate change, social-ecological and disaster risk sciences (Lei et al., 2014). A resilient system such as a wetland should be able to absorb disturbance without undergoing structural and functional change (Fabinyi et al., 2014). Building sustainable relationships between human and ecosystems or social-ecological resilience increases general security and contributes to enhancing the quality of life for the present and future generations (Takeuchi et al., 2014; UN, 1987). However, while advocating for the promotion of wetlands resilience in the study area, care should be taken not to compromise the resilience of the local community as a whole since there are often trade-offs with such actions (Fabinyi et al., 2014). Wetlands are only a form of natural capital or asset to which the other seven forms of capitals need to be added and managed sustainably and holistically.

\section{A Management Framework for Wetland Resilience}

In South Africa, wetland management has always been reactive with much focus on rehabilitation works carried out by a government public work programme known as Working for Wetlands. There is, however, a need to build wetland resilience by adopting a holistic management approach that is both proactive and reactive. Therefore an integrated wetland management framework (Fig. 14) is recommended in this study, which will help build wetland resilience in the eastern Free State. This framework can be adopted in other parts of the world with little or no alterations to suit local conditions.
The proposed wetland management framework integrates disaster risk reduction and climate change adaptation into wetland management. Such a holistic approach improves wetland resilience to various stressors. Information from various models such as the Disaster Risk Reduction Framework (UNISDR, 2004), Social-Ecological System Model (CDC, 2015) and the Climate Change Framework (IPCC, 2007) were assembled to build the framework. Additionally, extensive literature review and primary data collected in this study were brought together in the formulation of the proposed framework (Fig. 14). The Integrated Wetland Management Framework involves two broad sub-plans. First is the preparedness sub-plan, which is informed by proactive activities. The preparedness plan includes activities such as wetland risk and vulnerability assessment, which forms the foundation of the disaster risk reduction and climate change adaptation. The preparedness section highlights the fact that any meaningful disaster risk reduction and climate change adaptation measures should be informed by a meticulous risk and vulnerability assessment of the wetland. From the risk assessment results, appropriate preventive and/or mitigation measures are then put in place, which either reduce or prevent the stressors (for example effective legislations that prevent pollution of wetlands) or reduce the vulnerability of the wetlands to external stressors (for example better land use system that improves the ecological status of wetlands and therefore assist wetlands to cope and adapt to climate change). The second part of the proposed framework is the response sub-plan, which deals with technical issues related to rehabilitation and restoration of already degraded or lost wetlands. The response plan with technical details is best handled by specialised agents like the Working for Wetlands Programme, wetland specialists and technicians. 


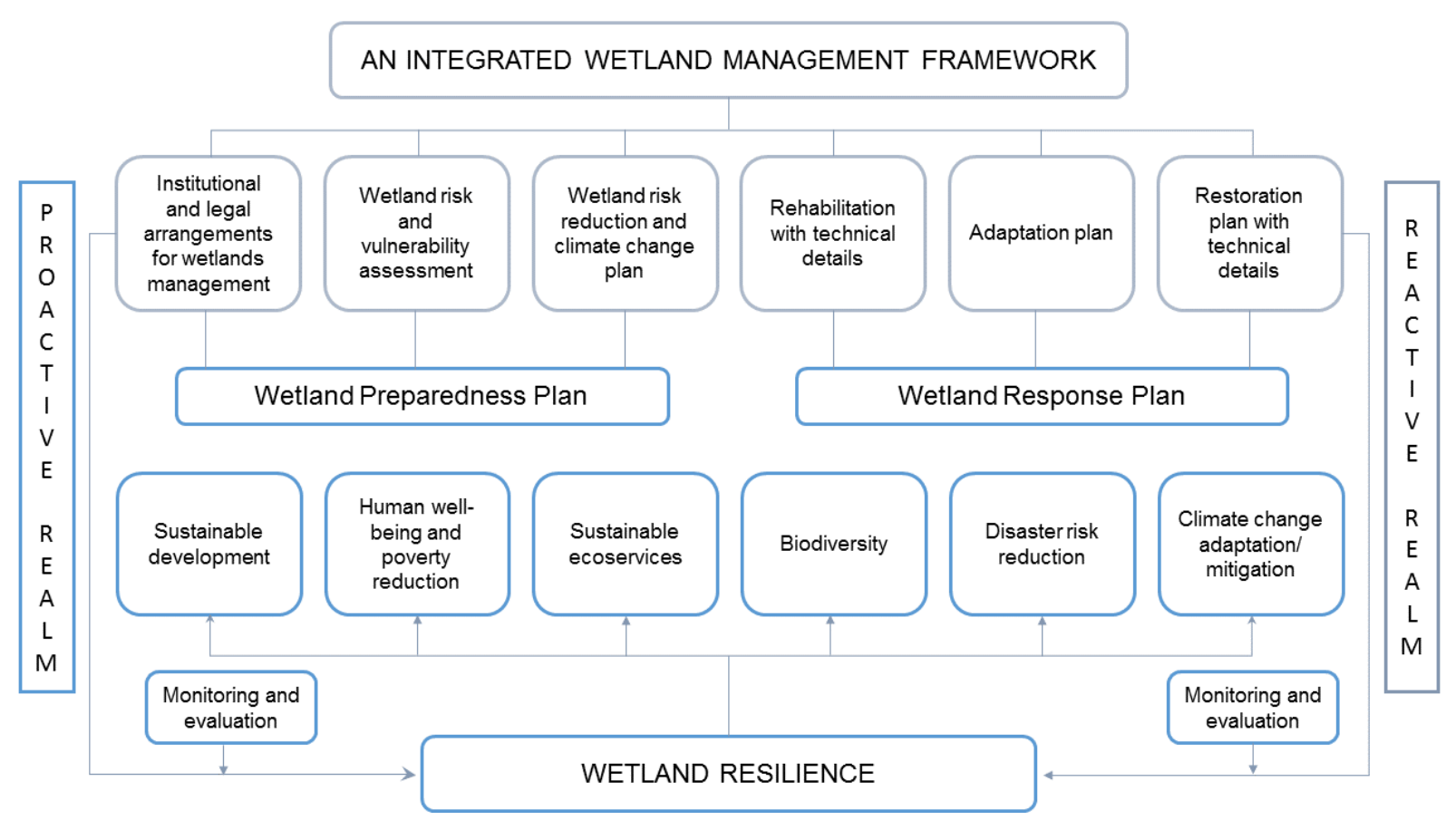

Fig. 14. Proposed integrated framework for wetland management for the eastern Free State province, South Africa, Source: Author's own (2016)

Both sub plans need constant monitoring and evaluation as there may be deviations from the intended aims of the strategies. Appropriate corrective measures can then be put in place to support either of the two sub plans of the framework.

The framework is work in progress as quantifiable indicators need to be formulated and added. Additionally, longitudinal monitoring and adjustments should be made to the framework. Both commercial and emerging farmers, the local community, conservationists, environmentalists, climate change specialists and disaster risk management practitioners will find this framework and the embedded concepts very useful.

\section{Conclusion}

Wetlands in the study area are valuable for agriculture (crop and animal grazing), but they also perform other functions and supply different ecological services, which are vital for the survival and growth of the local community. Many of these wetlands are facing severe threats, which are linked to hazards like drought, veld fire and flood. The impact of climate change has added to the stressors on wetlands. Ignorance of wetland functions and values as well as poorly functioning laws, policies and institutional arrangements contribute to wetland vulnerability in the study area. While the idea of managing wetlands for disaster risk reduction and climate change adaptation was evident in protected areas and practiced by chance in private wetlands, this was not the case with communal wetlands which are the most degraded wetlands in the area. An Integrated Wet land Management Framework is proposed, which incorporates disaster risk reduction and climate change adaptation and includes both pro-active and reactive measures.

The author's contribution in the field of environmental management is to propose a different approach in wetlands management to build wetland resilience that will better mitigate the negative impacts of disaster risks and climate change. This approach as captured in the proposed wetland management framework is holistic and applies system thinking. The approach integrates disaster risk reduction and climate change strategies into ecosystem management using wetlands as an example. The proposed management approach is both proactive and reactive with a monitoring and evaluation component built into the framework. Though the framework was developed for the specific case of wetlands management in the eastern Free State in South Africa, it could be applied to other parts of the world and for other ecosystems with little adjustments to suit local conditions.

\section{Acknowledgement}

We would like to acknowledge the contribution of the Southern African Systems Analysis Centre, the National Research Foundation and the Department of Science and Technology in South Africa as well as the International Institute for Applied System Analysis for 
enabling the corresponding author attend a workshop on system thinking approach that was applied in this article.

\section{Author's Contributions}

Johanes A. Belle: Primary and secondary data collection, literature review, drafting, editing and placement of the manuscript.

Nacelle Collins: Primary data collection, proof reading, editing and field supervision.

Andries Jordaan: Primary data collection, proof reading and field supervision.

\section{Ethics}

This article is original and contains unpublished material. The corresponding author confirms that all of the other authors have read and approved the manuscript and there are no ethical issues involved.

\section{References}

Arbogast, A.F., 2011. Discovering Physical Geography. 2nd Edn, Wiley Custom Learning, Hoboken, NJ, USA, ISBN-10: 9780470955833 , pp: 694.

Babbie, E., J. Mouton, P. Vorster and B. Prozesky, 2008. The Practice of Social Research. 1st Edn, Oxford University Press South Africa, Cape Town, South Africa.

Bertram, C. and I. Christiansen, 2014. Understanding Research: An Introduction to Reading Research. 1st Edn., Van Schaik, Pretoria, ISBN-10: 9780627031175 , pp: 2013.

Bookchin, M., 1993. What is social ecology? Institute for Social Ecology.

Burns, N. and S.K. Grove, 2005. The Practice of Nursing Research: Conduct, Critique and Utilization. 5th Edn., Elsevier/Saunders, St. Louis, Mo., ISBN-10: 9780721606262, pp: 780.

CDC, 2015. The social-ecological model: A framework for prevention. U.S. Department of Health and Human Services, Centre for Disease Control, USA.

CNRD/PEDRR, 2013. Disasters, environment and risk reduction - Eco-DRR master's module: Instructor's manual. Center for Natural Resources and Development/Partnership for Environment and Disaster Risk Reduction, Cologne and Geneva: CNDR-PEDRR.

Collins, N.B., 2006. Wetlands: The Basics and Some More. 1st Edn., Department of Water Affairs and Forestry, Bloemfontein, South Africa, ISBN-10: 0-86886-708-X, pp: 121.

Collins, N.B., 2011. Phytosociology and ecology of selected depression (PAN) and valley-bottom wetlands of the free state province. $\mathrm{PhD}$ thesis, University of the Free State, Bloemfontein, South Africa.
Coppola, D.P., 2011. Introduction to International Disaster Management. 2nd Edn, Butterworth-Heinemann, Boston, ISBN-10: 9780123821744, pp: 684.

Costanza, R., R. De Groot, P. Sutton, S. Van der Ploeg and S.J. Anderson et al., 2014. Changes in the global value of ecosystem services. Glob. Environ. Change, 26: 152-158. DOI: 10.1016/j.gloenvcha.2014.04.002

Creswell, J.W., 2003. Research Design: Qualitative, Quantitative and Mixed Method Approaches. 2nd Edn., Sage Publications, Thousand Oaks, Calif., ISBN-10: 9780761924418 , pp: 246.

De Vos, A.S., H. Strydom, C.B. Fouché and C.S.L. Delport, 2005. Research at Grass Roots - for the Social Sciences and Human Service Profession. 3rd Edn., Van Schaik, Pretoria, ISBN-10: 0627026125, pp: 471.

Dione, O., 2014. A paradigm shift for guarding delta cities against floods. The World Bank.

Dini, J., 2004. Restoring wetlands and healing a nation: South Africa's working for wetlands program. Natl. Wetland Newslett., 26: 1-7.

Doswald, N. and M. Estrella, 2015. Promoting ecosystems for disaster risk reduction and climate change adaptation: Opportunities for integration. UNEP Switzerland: Post-Conflict and Disaster Management.

Dudley, N., C. Buyck, N. Furuta, C. Pedrot and F, Renaud et al., 2015. Protected Areas as Tools for Disaster Risk Reduction: A Handbook for Practitioners. 1st Edn., MOEJ and IUCN, Switzerland, ISBN-10: 978-2-8317-1711-1, pp: 44.

Estrella, M. and N. Saalisma, 2011. Demonstrating the role of ecosystems-based management for disaster disk reduction. UNISDR GAR Report of Partnership for Environment and Disaster Risk Reduction, UNISDR, Geneva.

Fabinyi, M., L. Evans and S.J. Foale, 2014. Socialecological systems, social diversity and power: Insights from anthropology and political ecology. Ecol. Society, 19: 1-12. DOI: 10.5751/ES-07029-190428

Flora, C.B., J.L. Flora and S. Fey, 2003. Rural Communities: Legacy and Change. 2nd Edn., Westview Press, Boulder, Colo, ISBN-10: 0813340519, pp: 384.

Gitay, H., C.M. Finlayson and N. Davidson, 2011. A framework for assessing the vulnerability of wetlands to climate change. Ramsar Technical Report No. 5, CBD Technical Series No. 57. Ramsar Convention Secretariat, Gland, Switzerland and Secretariat of the Convention on Biological Diversity, Montreal, Canada.

Gray, M.J., H.M. Hagy, J.A. Nyman and J.D. Stafford, 2013. Management of wetlands for wildlife. USGS Staff - Published Research, Paper 803, Digital Commons at University of Nebraska - Lincoln.

Grundling, P.L., 2012. An overview of expected impacts of climate change on wetlands of South Africa. COP17 Side Event: Ecosystem-based AdaptationSouth Africa case studies. COP17, Durban. 
Gupta, A.K. and S.S. Nair, 2012. Ecosystem approach to disaster risk reduction. National Institute of Disaster Management, PreventionWeb, New Delhi.

IFRC, 2013. About disaster management. International Federation of the Red Cross and Red Crescent.

IPCC, 2007. Intergovernmental panel on climate change. Fourth Assessment Report, IPCC, Cambridge University Press, Cambridge, United Kingdom.

IPCC, 2014. Synthesis for policy makers. Fifth Assessment Report, Intergovernmental Panel on Climate Change, IPCC, Geneva.

Jordaan, A.J., 2017. Theoretical models for disaster risk reduction. Lecture Notes for DiMM 5810, University of the Free State, Bloemfontein.

Kakuru, W., N. Turyahabwe and J. Mugisha, 2013. Total economic value of wetlands products and services in Uganda. Sci. World J., 2013: 1-14. DOI: $10.1155 / 2013 / 192656$

Kidd, M., 2011. Environmental Law. 2nd Edn., Cape Town: Juta.

Kitchin, R. and N.J. Tate, 2000. Conducting Research in Human Geography: Theory, Methodology and Practice. 1st Edn., Prentice Hall, Harlow, ISBN-10: 0582297974, pp: 330.

Kotze, D.C., C.M. Breen, I.Z. Nxele and J. Kareko, 2009. Wet-management review: The impact of natural resources management programmes on wetlands in South Africa. WRC Report No.TT 335/09, Water Research Commission, Pretoria.

Kotze, D.C., G.C. Marneweck, A.L. Batchelor, D.S. Lindley and N.B. Collins, 2007. Wet-EcoServices: A technique for rapidly assessing ecosystem services supplied by wetlands. WRC Report No.TT 339/09, Water Research Commission, Pretoria.

Lei, Y., J. Wang, Y. Yue, H. Zhou and W. Yin, 2014. Rethinking the relationships of vulnerability, resilience and adaptation from a disaster risk perspective. Natl. Hazards, 70: 609-627. DOI: $10.1007 / \mathrm{s} 11069-013-0831-7$

Maree, K., 2007. First Steps in Research. 1st Edn., Van Schaik, Pretoria, ISBN-10: 0627026885, pp: 339.

Mattos, D., 2015. Community capital framework as a measure of community development. Cornhusker Economics. Institute of Agriculture and Natural Resources, University of Nebraska.

MEA, 2005. Ecosystems and human well-being: Wetlands and water synthesis. Millennium Ecosystem Assessment, World Resources Institute, Washington DC.

Mitchell, T. and M. Van Aalst, 2008. Convergence of disaster risk reduction and climate change adaptation: A review for DFID. Department for International Development (DFID), UK.

Mouton, J., 2001. How to Succeed in Your Master's and Doctoral Studies: A South African Guide and Resource Book. 1st Edn., Van Schaik, Pretoria, ISBN-10: 062702484X, pp: 280.
Nel, J.L., A. Driver, W. Strydom, A. Maherry and C. Petersen et al., 2011. Atlas of freshwater ecosystem priority areas in South Africa: Maps to support sustainable development of water resources. WRC Report No. TT 500/11, Water Research Commission, Pretoria.

NSTC, 2015. Ecosystem-service assessment: Research needs for coastal green infrastructure. Washington D.C.: Committee on Environment, Natural Resources, and Sustainability, National Science and Technology Council.

Oberholster, P.J., K. McMillan, K.Durgapersad, A.M. Botha and A.R. De Klerk, 2014. The development of a Wetland Classification and Risk Assessment Index (WCRAI) for non-wetland specialists for the management of natural freshwater wetland ecosystems. Water Air Soil Pollut., 225: 1-5. DOI: $10.1007 / \mathrm{s} 11270-013-1833-5$.

Okeke, C. and M.M. Van Wyk, 2015. Educational Research: An African Approach. 1st Edn., Oxford University Press Southern Africa, Cape Town, ISBN-10: 0190409134, pp: 584.

Ollis, D., K. Snaddon, N. Job and N. Mbona, 2013. Classification System for Wetlands and Other Aquatic Ecosystems in South Africa: User Manual: Inland Systems. 1st Edn., South African National Biodiversity Institute, Pretoria, ISBN-10: 1919976752, pp: 110.

PEDRR ,2013. Understanding environment, livelihoods and disaster linkages. PEDRR Input into Post-2015 Global Framework on Disaster Risk Reduction. Partnership on Environment and Disaster Risk Reduction.

PEDRR, 2014. PEDRR input into Post-2015 Global Framework on Disaster Risk Reduction. Partnershipon Environment and Disaster Risk Reduction.

Peters, D.J., 2016. Community Capital Framework. Guest Lecture DSN S 546-Interdisciplinary Design Studio, Iowa State University, USA.

Rakotsoane, F.C.L. and M.A. Rakotsoane, 2006. The ABC of Research Project, Dissertation and Thesis Proposal Writing. Choice Publishing Company, Roma, ISBN-10: 9991163867, pp: 111.

RCS, 2010. Wise Use of Wetlands: Concepts and Approaches for the Wise Use of Wetlands. Ramsar Handbooks for the Wise Use of Wetlands, 4th Edn., Ramsar Convention Secretariat, Gland.

Renaud, F.G., K. Sudmeier-Rieux and N. Estrella, 2013. The Role of Ecosystems in Disaster Risk Reduction. 1st Edn., United Nations University Press, Tokyo, ISBN-10: 9280812211, pp: 486.

Renaud, F.G., K. Sudmeier-Rieux, M. Estrella and U. Nehren, 2016. Ecosystem-based Disaster Risk Reduction and Adaptation in Practice. 1st Edn., Springer International Publishing, Switzerland, ISBN-10: 3319436333, pp: 598.

Reynolds, S.J., R.V. Rohli, J.K. Johnson, P.R. Waylen and M.A. Francek, 2015. Exploring Physical Geography. The McGraw-Hill Companies, Inc, New York, ISBN-10: 1259205630. 
RSA, 1998. National Water Act (NWA), Act 36 of 1998. Government Gazette, Cape Town, Republic of South Africa.

RSS, 2014. Resilience to extreme weather. The Royal Society of Science Policy Centre, London.

Stein, B.A., P. Glick, N. Edelson and A. Staudt, 2014. Climate-smart conservation: Putting adaptation principles into practice. National Wildlife Federation, Washington, D.C., USA.

Strahler, A.H. and A.N. Strahler, 2005. Physical Geography: Science and Systems of the Human Environment. 3rd Edn., John Willey and Sons, New York, ISBN-10: 0471657646, pp: 794.

Suppasri, A., N. Shuto, F. Imamura, S. Koshimura and E. Mas et al., 2013. Lessons learned from the 2011 great east Japan Tsunami: Performance of tsunami counter measures, coastal building and tsunami evacuation in Japan. Pure Applied Geophys., 170: 993-1018.

Takeuchi, K., T. Elmqvist, M. Hatakeyama, J. Kauffman and N. Turner et al., 2014. Using sustainability science to analyse social-ecological restoration in NE Japan after the great earthquake and tsunami of 2011. Sustain. Sci., 9: 513-526. DOI: $10.1007 / \mathrm{s} 11625-014-0257-5$

Talberth, J., E. Gray, L. Yonavjak and T. Gartner, 2013. Green versus gray: Nature's solutions to infrastructure demands. Solutions J., 4: 40-47.

Thomalla, F., T. Downing, E. Spanger-Siegfried, G. Han and J. Rockström, 2006. Reducing hazard vulnerability towards a common approach between disaster risk reduction and climate adaptation. Disasters, 30: 39-48.

TEEB, 2010. The economics of ecosystems and biodiversity for local and regional policy makers. The Economics of Ecosystems and Biodiversity, Progress Press, Malta.

Tidball, K.G. and M.E. Krasny, 2014. Greening in the Red Zone: Disaster, Resilience and Community Greening. 1st Edn., Springer, New York, ISBN-10: 978-90-481-9946-4, pp: 503.

Tietenberg, T.H. and L. Lewis, 2012. Environmental and Natural Resource Economics. 9th Edn., Pearson Education, Upper Saddle River, N.J., ISBN-10: 0131392573, pp: 666.

Turner, B.L., R.E. Kasperson, P.A. Matson, J.J. McCarthy and R.W. Corell et al., 2003. A framework for vulnerability analysis in sustainability science. Proc. Nat. Acad. Sci., 100: 8074-8079.

DOI: $10.1073 /$ pnas. 1231335100
Twigg, J., 2009. Characteristics of a disaster-resilient community: A guidance note. Version 2. University College of London, Gower Street, London.

UCI, 2015. What is social ecology? School of Social Ecology. University of California, Irvine.

UN, 1987. Report of the world commission on environment and development: Our common future. United Nations.

UNDP, 2015. A new sustainable development agenda: The SDGs. United Nations Development Programme.

UNEP, 2009. The role of ecosystem management in climate change adaptation and disaster risk reduction. Copenhagen Discussion Series. United Nations Environmental Programme (UNEP), Geneva.

UNEP, 2010. The role of ecosystems in developing a sustainable "Green Economy". Ecosystem Management Policy Brief 2. United Nations Environmental Programme (UNEP), Geneva.

UNFCCC, 2015. Draft Paris outcome. United Nations Framework Convention on Climate Change.

UNISDR, 2004. Living with risk: A global review of disaster reduction initiatives. Volume I. UN, United Nations International Strategy for Disaster Reduction, Geneva, Switzerland.

UNISDR, 2013. Disaster impacts 2000-2012. United Nations International Strategy for Disaster Reduction.

UNISDR, 2015. The Sendai framework for disaster risk reduction 2015-2030. United Nations International Strategy for Disaster Reduction (UNISDR), Geneva.

Van Wyk, M.M., 2016. Philosophies of research for postgraduate students. Powerpoint presentation at the postgraduate workshop on 07/03/2016. University of the Free State, Bloemfontein, South Africa

Virapongse, A., S. Brooks, E.C. Metcalf and L.N. Alessa, 2016. A social-ecological systems approach for environmental management. J. Environ. Manage., 178: 83-91. DOI: 10.1016/j.jenvman.2016.02.028

Walker, B., S. Carpenter, J. Anderies, N. Abel and G.S. Cumming et al., 2002. Resilience management in social-ecological systems: A working hypothesis for a participatory approach. Conserv. Ecol., 6: 14-14.

Wisner, B., P. Blaikie, T. Cannon and I. Davis, 2004. At Risk: Natural Hazards, People's Vulnerability and Disasters. 2nd Edn., Routledge Taylor and Francis Group, London, ISBN-10: 0415252164, pp: 496. 